University of Nebraska - Lincoln

DigitalCommons@University of Nebraska - Lincoln

Publications, Agencies and Staff of the U.S.

Department of Commerce

U.S. Department of Commerce

2012

\title{
Seasonal zooplankton dynamics in Lake Michigan: Disentangling impacts of resource limitation, ecosystem engineering, and predation during a critical ecosystem transition
}

\author{
Henry A. Vanderploeg \\ National Oceanic and Atmospheric Administration, henry.vanderploeg@noaa.gov \\ Steven A. Pothoven \\ Great Lakes Environmental Research Laboratory, steve.pothoven@noaa.gov \\ Gary L. Fahnenstiel \\ Great Lakes Environmental Research Laboratory, gary.fahnenstiel@noaa.gov \\ Joann F. Cavaletto \\ National Oceanic and Atmospheric Administration, joann.cavaletto@noaa.gov \\ James R. Liebig \\ National Oceanic and Atmospheric Administration, jim.liebig@noaa.gov \\ See next page for additional authors \\ Follow this and additional works at: https://digitalcommons.unl.edu/usdeptcommercepub \\ Part of the Environmental Sciences Commons
}

\footnotetext{
Vanderploeg, Henry A.; Pothoven, Steven A.; Fahnenstiel, Gary L.; Cavaletto, Joann F.; Liebig, James R.; Stow, Craig A.; Nalepa, Thomas F.; Madenjian, Charles P.; and Bunnell, David B., "Seasonal zooplankton dynamics in Lake Michigan: Disentangling impacts of resource limitation, ecosystem engineering, and predation during a critical ecosystem transition" (2012). Publications, Agencies and Staff of the U.S. Department of Commerce. 406.

https://digitalcommons.unl.edu/usdeptcommercepub/406

This Article is brought to you for free and open access by the U.S. Department of Commerce at DigitalCommons@University of Nebraska - Lincoln. It has been accepted for inclusion in Publications, Agencies and Staff of the U.S. Department of Commerce by an authorized administrator of DigitalCommons@University of Nebraska - Lincoln.
} 


\section{Authors}

Henry A. Vanderploeg, Steven A. Pothoven, Gary L. Fahnenstiel, Joann F. Cavaletto, James R. Liebig, Craig A. Stow, Thomas F. Nalepa, Charles P. Madenjian, and David B. Bunnell 


\title{
Seasonal zooplankton dynamics in Lake Michigan: Disentangling impacts of resource limitation, ecosystem engineering, and predation during a critical ecosystem transition
}

\author{
Henry A. Vanderploeg a,*, Steven A. Pothoven ${ }^{\text {b }}$, Gary L. Fahnenstiel ${ }^{\text {b }}$, Joann F. Cavaletto a , James R. Liebig a , \\ Craig A. Stow ${ }^{a}$, Thomas F. Nalepa ${ }^{a}$, Charles P. Madenjian ${ }^{\text {c}}$, David B. Bunnell ${ }^{\text {c }}$ \\ a National Oceanic and Atmospheric Administration, Great Lakes Environmental Research Laboratory, 4840 S. State Road, Ann Arbor, MI 48108, USA \\ b Great Lakes Environmental Research Laboratory, Lake Michigan Field Station, 1431 Beach St., Muskegon, MI 49441, USA \\ ' U.S. Geological Survey, Great Lakes Science Center, 1451 Green Road, Ann Arbor, MI 48105, USA
}

\section{A R T I C L E I N F O}

\section{Article history:}

Received 20 October 2011

Accepted 25 January 2012

Available online $\mathrm{xxxx}$

Communicated by Joseph C. Makarewicz

\section{Keywords:}

Zooplankton

Planktivory

Food limitation

Tipping point

Climate

\begin{abstract}
A B S T R A C T
We examined seasonal dynamics of zooplankton at an offshore station in Lake Michigan from 1994 to 2003 and 2007 to 2008. This period saw variable weather, declines in planktivorous fish abundance, the introduction and expansion of dreissenid mussels, and a slow decline in total phosphorus concentrations. After the major expansion of mussels into deep water (2007-2008), chlorophyll in spring declined sharply, Secchi depth increased markedly in all seasons, and planktivorous fish biomass declined to record-low levels. Overlaying these dramatic ecosystem-level changes, the zooplankton community exhibited complex seasonal dynamics between 1994-2003 and 2007-2008. Phenology of the zooplankton maximum was affected by onset of thermal stratification, but there was no other discernable effect due to temperature. Interannual variability in zooplankton biomass during 1994 and 2003 was strongly driven by planktivorous fish abundance, particularly age-0 and age-1 alewives. In 2007-2008, there were large decreases in Diacyclops thomasi and Daphnia mendotae possibly caused by food limitation as well as increased predation and indirect negative effects from increases in Bythotrephes longimanus abundance and in foraging efficiency associated with increased light penetration. The Bythotrephes increase was likely driven in part by decreased predation from yearling and older alewife. While there was a major decrease in epilimnetic-metalimnetic herbivorous cladocerans in 2007-2008, there was an increase in large omnivorous and predacious calanoid copepods, especially those in the hypolimnion. Thus, changes to the zooplankton community are the result of cascading, synergistic interactions, including a shift from vertebrate to invertebrate planktivory and mussel ecosystem impacts on light climate and chlorophyll.
\end{abstract}

Published by Elsevier B.V. on behalf of International Association for Great Lakes Research.

\section{Introduction}

Since the mid 1980s, Lake Michigan has undergone dramatic changes in its food web likely driven by changes in vertebrate planktivory, nutrient loading, and disruption of the food web in the middle from invasive species. These perturbations included: (1) a gradual decrease in total phosphorus (TP) loading (Mida et al., 2010); (2) increased control of the planktivorous alewife (Alosa pseudoharengus) by introduction of Pacific salmon (Madenjian et al., 2005, 2010); (3) the invasion of the visual-feeding spined predatory cladoceran Bythotrephes longimanus in the mid 1980s from northern Europe

\footnotetext{
* Corresponding author. Tel.: + 17347412284.

E-mail addresses: henry.vanderploeg@noaa.gov (H.A. Vanderploeg), steve.pothoven@noaa.gov (S.A. Pothoven),gary.fahnenstiel@noaa.gov (G.L. Fahnenstiel), joann.cavaletto@noaa.gov (J.F. Cavaletto), jim.liebig@noaa.gov (J.R. Liebig), craig.stow@noaa.gov (C.A. Stow), tom.nalepa@noaa.gov (T.F. Nalepa), cmadenjian@usgs.gov (C.P. Madenjian), dbunnell@usgs.gov (D.B. Bunnell).
}

(Lehman, 1987; Vanderploeg et al., 2002); (4) invasion by a host of Ponto-Caspian species, including zebra (Dreissena polymorpha) and quagga mussels (Dreissena rostriformis bugensis) during the 1990s (Vanderploeg et al., 2002); and (5) loss of the spring phytoplankton bloom in 2007 and 2008 (Fahnenstiel et al., 2010) likely caused by intense filtering during winter and spring by quagga mussels following their massive population expansion into deep water starting in 2004 (Nalepa et al., 2010; Vanderploeg et al., 2010).

Given that many of changes in these potential drivers have occurred relatively simultaneously, disentangling the relative importance of each of these perturbations on specific species, guilds, or trophic levels is a daunting, if not impossible, task. Moreover, effects can be complex and indirect, particularly for food web disruption by invasive species. For example, mussels can be considered ecosystem engineers because they increase light intensity (from filtering activities) and sequester $P$ in their tissues, in addition to their more recognized role of filtering phytoplankton and microzooplankton from the water column (Hecky et al., 2004; Vanderploeg et al., 2002; 
Vanderploeg et al., 2010). The increase in light intensity has the potential for disrupting the pelagic food web through mediation of visual predation rates of vertebrate predators and Bythotrephes as well as and habitat selection by fishes (Muirhead and Sprules, 2003; Pangle and Peacor, 2009; Vanderploeg et al., 2002) and diel vertical migration (DVM) of the pelagic food web, which is sensitive to light intensity (e.g., Vanderploeg et al., 2009; Wright et al., 1980). In another example, Bythotrephes can have a large negative impact on zooplankton through induction of greater downward vertical migration of zooplankton like Daphnia into cool suboptimal feeding habitats during the day (Pangle and Peacor, 2006).

On account of all these changes in potential forcing variables, we would expect to see changes in seasonal dynamics of zooplankton. In the past, knowledge of changes in Lake Michigan zooplankton in the offshore region came from two kinds of studies: (1) documentation of dramatic changes during summer in response to stressors such as non-indigenous species and weather (e.g., Lehman, 1991; Scavia et al., 1986; Wells, 1970) examined over a few years, or (2) long-term EPA surveys of offshore stations during early spring and late summer cruises (e.g., Barbiero et al., 2009a; Makarewicz et al., 1995). Both may miss important seasonal patterns, and the highly dynamic plankton succession may not be in any seasonal steady state during the surveys. Nor are snapshots useful for specifying annual biomass of zooplankton, which would be important for understanding interannual variability patterns and the resource base available to forage fishes. Further, seasonal patterns themselves are potentially useful for parsing out potential driving forces (e.g. Jeppesen et al., 2005; Straile and Adrian, 2000).

There are no other extensive multi-year seasonal time series data for offshore Lake Michigan. In 1973-1974, Torke (1975) completed an intense study of population dynamics, with sampling once per week during the stratified season at an offshore station near Milwaukee that nicely defined the seasonal dynamics, but it was limited to 15 months. Evans (1990) collected seasonal time series during the 1970 s and early 1980 s, but they were restricted to the nearshore ( $\leq 45 \mathrm{~m})$.

Seasonal dynamics of zooplankton from 1994 to 2003 are of especial interest because the period includes the coldest $(1994,1996)$ and warmest (1998) spring water temperatures in recent history (see below; Wang et al., 2010), allowing us to examine possible influences of interannual weather variability on plankton dynamics. Onset of thermal stratification can affect phenology of plankton succession and possible temporal mismatch between predator and prey (Durant et al., 2007; Gerten and Adrian, 2000; Jeppesen et al., 2005; Straile and Adrian, 2000). In addition, the largest year-class of alewives (the dominant zooplanktivorous fish) since 1970 was produced during 1998, the year with the warmest spring water temperature (Madenjian et al., 2005). During the 1960s and 1970s, alewives were thought to be a dominant force affecting zooplankton community structure (Wells, 1970).

The period 2007-2008 captures conditions associated with the major expansion of quagga mussels into deep water, which started in 2004 (Bunnell et al., 2009b; Nalepa et al., 2010), and the loss of the spring phytoplankton bloom (Fahnenstiel et al., 2010; Vanderploeg et al., 2010); thus, it could represent a critical transition to bottom-up forces strongly affecting zooplankton dynamics. In fact, Kerfoot et al. (2010) observed some zooplankton species decreased along cross-lake transects during April in 2007 and 2008 relative to 2006, which they attributed to the loss of the bloom. Concurrently, the biomass of planktivorous prey fishes reached record low levels (Madenjian et al., 2010), which could result in lower direct planktivory and thus mitigate the effects of low phytoplankton abundance on herbivorous zooplankton.

We describe the seasonal dynamics of zooplankton and examine potential causes of interannual variability by looking at the behavior of the time series relative to resource availability (chlorophyll, as surrogate for phytoplankton) adapted from previously reported studies (Fahnenstiel et al., 2010; Mida et al., 2010), planktivory (fish and invertebrate predators), temperature, and light available for predation, as measured by Secchi disk. We explicitly compare dynamics in 1994-2003 with those in 2007-2008, periods before and during the major expansion of mussels into deep water.

\section{Methods}

\section{Zooplankton collection and counting}

Zooplankton were collected biweekly to monthly from 1994 to 2003 and 2007 to $2008 \mathrm{March} /$ April through November/December at our $110-\mathrm{m}$ site (M110; $43^{\circ} 11.29^{\prime} \mathrm{N}, 86^{\circ} 32.16^{\prime} \mathrm{W}$ ) in SE Lake Michigan approximately 11 nautical miles west of Muskegon, Michigan (except for 2001, when collections did not start until June). Sample collection and analysis followed methods described by Vanderploeg et al. (2007). In brief, samples were collected using duplicate vertical tows of a $50-\mathrm{cm}$ diameter, $2.5-\mathrm{m}$ long, $153-\mu \mathrm{m}$ mesh, conical net equipped with an internal calibrated flow meter from 1 to $2 \mathrm{~m}$ above the bottom to the surface. Zooplankton were narcotized with Alka-Seltzer and preserved in 2-4\% sugar formalin solution (Haney and Hall, 1973). A minimum of 550 zooplankton were identified for each sample taken from each replicate tow. To count large predatory cladocerans, such as Bythotrephes, the whole sample was rinsed through a $600-\mu \mathrm{m}$ mesh sieve, and all individuals were counted.

All cladocerans and adult copepods were identified to species, immature copepodites to genus, and cyclopoid and calanoid nauplii combined into one group using the keys of Wilson and Yeatman (1959), Brooks (1959), and Balcer et al. (1984). To determine zooplankton biomasses expressed as dry weight, length measurements were made on a subsample of taxa (10 adult copepods and 25 copepodites or cladocerans) that were over $10 \%$ of the total density using Image Pro Plus image analysis software (Media Cybernetics, Silver Spring, MD). In the case of large predatory cladocerans, all individuals were measured, or up to 100 individuals if more than that were present. Biomass was determined using published lengthweight regressions (Culver et al., 1985; Makarewicz and Jones, 1990; Malley et al., 1989). We recognize that these length-weight regressions underestimate biomass of adult Leptodiaptomus sicilis and Limnocalanus macrurus during summer and fall, when these species lay down abundant lipid reserves in preparation for reproduction (Doubek and Lehman, 2011; Vanderploeg et al., 1992, 1998). For zooplankton taxa that comprised less than $10 \%$ of the total density, a default weight from the literature was used to determine biomass for all taxa except Bythotrephes (Hawkins and Evans, 1979).

\section{Summary of relevant zooplankton ecology}

To aid interpretation of results, we summarized important features of species ecology that are relevant to their changing abundance (Table 1). Relevant features included size, habitat (location in water column), feeding mode, and their ability to escape predators, both vertebrate and invertebrate.

\section{Quantifying effective planktivorous fish abundance}

To explore potential impacts of fish predation on zooplankton abundance, we performed correlation analyses between biomass of zooplankton and alewives (Alosa pseudoharengus), the size-selective planktivorous fish species in Lake Michigan that was relatively abundant throughout the study period (see below) and has the greatest per capita impact to mesozooplankton (Bunnell et al., 2006; Davis et al., 2007; Madenjian et al., 2002; Pothoven and Vanderploeg, 2004). As age0 fish, alewives are found in the epilimnion or metalimnion during dayand night, where they feed on zooplankton; however, they are 
Table 1

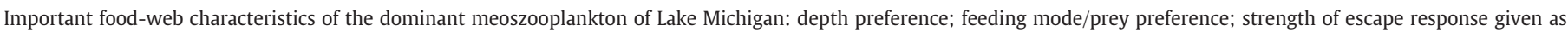

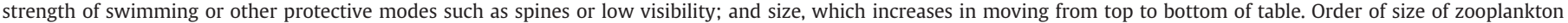
is taken primarily from Liebig and Vanderploeg (2008) and secondarily from Hawkins and Evans (1979).

\begin{tabular}{|c|c|c|c|c|}
\hline \multirow[t]{2}{*}{ Taxon } & \multicolumn{2}{|c|}{ Habitat $^{\mathrm{a}}$} & \multirow[t]{2}{*}{ Probable feeding mode } & \multirow[t]{2}{*}{ Escape reaction $^{1}$} \\
\hline & Night & Day & & \\
\hline Copepod nauplii & $\mathrm{E}$ & E & Omnivore-protozoa and phytoplankton ${ }^{\mathrm{b}}$ & Moderate-weak \\
\hline Bosmina longirostris & $\mathrm{E}$ & M-UH & Filter feeder ${ }^{c}$ & Very weak \\
\hline Diacyclops thomasi $\mathrm{C} 1-\mathrm{C} 5$ & $\mathrm{E}$ & $\mathrm{M}$ & Carnivore-microzooplankton ${ }^{\mathrm{c,d}}$ & Moderate \\
\hline Epischura lacustris $\mathrm{C} 1-\mathrm{C} 5$ & $\mathrm{E}$ & E & Omnivore-carnivore-microzooplankton and small crustaceans ${ }^{\mathrm{b}, \mathrm{h}}$ & Moderate \\
\hline D. thomasi C6 & $\mathrm{E}$ & M & Carnivore-microzooplankton $^{\mathrm{d}}$ & Moderate \\
\hline Diaptomids $\mathrm{C} 1-\mathrm{C} 5$ & & & Omnivore-protozoa and phytoplankton ${ }^{\mathrm{b}, \mathrm{c}, \mathrm{e}}$ & Moderate \\
\hline Leptodiaptomus minutus $\mathrm{C} 6$ & E & E-M & Omnivore-protozoa and phytoplankton ${ }^{\mathrm{a}, \mathrm{b}, \mathrm{d}}$ & Moderate \\
\hline L. ashlandi $\mathrm{C} 6$ & M & $\mathrm{M}$ & Omnivore-protozoa and phytoplankton ${ }^{\mathrm{b}, \mathrm{c}, \mathrm{e}}$ & Moderate \\
\hline Limnocalanus marcrurus $\mathrm{C} 1-\mathrm{C} 5$ & & & Carnivore-microzooplankton and crustaceans $\mathrm{s}^{\mathrm{f}, \mathrm{g}}$ & Moderate \\
\hline Leptodiaptomus sicilis $\mathrm{C} 6$ & $\mathrm{H}$ & $\mathrm{H}$ & Omnivore-protozoa and phytoplankton ${ }^{\mathrm{b}, \mathrm{c}, \mathrm{e}}$ & Moderate-strong \\
\hline Epischura lacustris C6 & E & M & Carnivore-protozoa, small crustaceans, and mussel veligers ${ }^{\mathrm{b}, \mathrm{g}, \mathrm{h}}$ & Moderate-strong \\
\hline Daphnia mendotae & $\mathrm{M}-\mathrm{E}$ & $\mathrm{UH}$ & Filter feeder ${ }^{c}$ & Weak-moderate \\
\hline L. macrurus C6 & $\mathrm{H}$ & $\mathrm{H}$ & Carnivore-crustacean zooplankton ${ }^{\mathrm{f}, \mathrm{g}}$ & Strong \\
\hline Bythotrephes longimanus & E-M & E-M & Visual-feeding-small and large cladocerans and copepod nauplii ${ }^{\mathrm{i}, \mathrm{j}, \mathrm{k}}$ & Weak, spine \\
\hline
\end{tabular}

${ }^{a}$ Habitat preferences from Barbiero et al. (2005) and Vanderploeg (unpublished data).

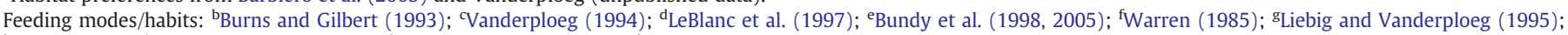
hWong (1981); ${ }^{\mathrm{i}}$ Vanderploeg et al. (1993); ${ }^{\mathrm{j}}$ Schulz and Yurista (1998); ${ }^{\mathrm{k}}$ Muirhead and Sprules (2003).

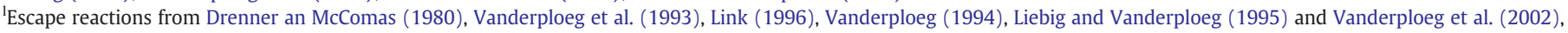
Pichlová-Ptáčníková and Vanderploeg (2011).

inefficient feeders on Bythotrephes, a major epilimnetic-metalimnetic invertebrate predator of zooplankton, as its tail spine foils ingestion by small fish (Branstrator and Lehman, 1996; Pothoven and Vanderploeg, 2004). Yearling and older (YAO) alewives are typically found the metalimnion or hypolimnion during the day and migrate into the metalimnion (Brandt et al., 1980; Wells, 1968) at night. Because of their relatively high position in the water column and preference for large prey, YAO alewives have high selectivity coefficients for Bythotrephes (Pothoven and Vanderploeg, 2004; Pothoven et al., 2007).

To quantify alewife abundances, we used the data from the USGS Great Lakes Science Center (GLSC) long-term bottom trawl survey of the Lake Michigan prey fish community (Bunnell et al., 2006; Hatch et al., 1981; Madenjian et al., 2005, 2010). These lake-wide estimates pertain to the region of the main basin of Lake Michigan between the 5-m and the 114-m depth contours (Bunnell et al., 2006). Based on total length, we divided lake-wide biomass estimates of alewives into two categories: age-0 fish and yearling and older (YAO) fish (Madenjian et al., 2005).

Age-0 alewives in the autumn are not efficiently captured with bottom trawls, and they are an unreliable indicator of future adult alewife abundance (Madenjian et al., 2005). Because of this, we opted to use an estimate of age- 0 alewife abundance based on the lake-wide biomass for age-3 alewives, which are efficiently captured, as a measure of year-class strength; that is, the biomass of age- 3 alewives was used as an index of age- 0 alewife abundance 3 years earlier (Madenjian et al., 2005). The index was calculated by dividing the biomass in a given year by the highest biomass observed in the series. We used a similar procedure to estimate abundance of age- 1 alewives. That is, we assumed our index of year-class strength in year $\mathrm{x}$ was also an index of age- 1 alewife abundance during year $\mathrm{x}+1$.

\section{Temperature, total phosphorus, and chlorophyll trends}

Concurrently with zooplankton, we collected information on temperature and chlorophyll (Chl), as well as total phosphorus (TP) concentration to see how nutrient availability changed over time. To examine correlations of zooplankton with temperature, we used near-surface epilimnetic temperature. Although we collected temperature from Seabird CTD casts on most sampling events, the sampling dates for temperatures were too spotty to give good time trends or average annual patterns. Instead, we used temperature data from epilimnetic thermistors located $0.6 \mathrm{~m}$ below the surface on a National
Data Buoy Center (NDBC) buoy (Station 45007) in the center of the southern basin that recorded temperatures at hourly intervals (http://www.ndbc.noaa.gov/station_history.php?station=45007). Typically data were available from March/April to November/December. Annual mean temperature (or temperatures averaged over selected months) was calculated by using monthly means (AprilNovember) of hourly temperature readings. To portray smooth time
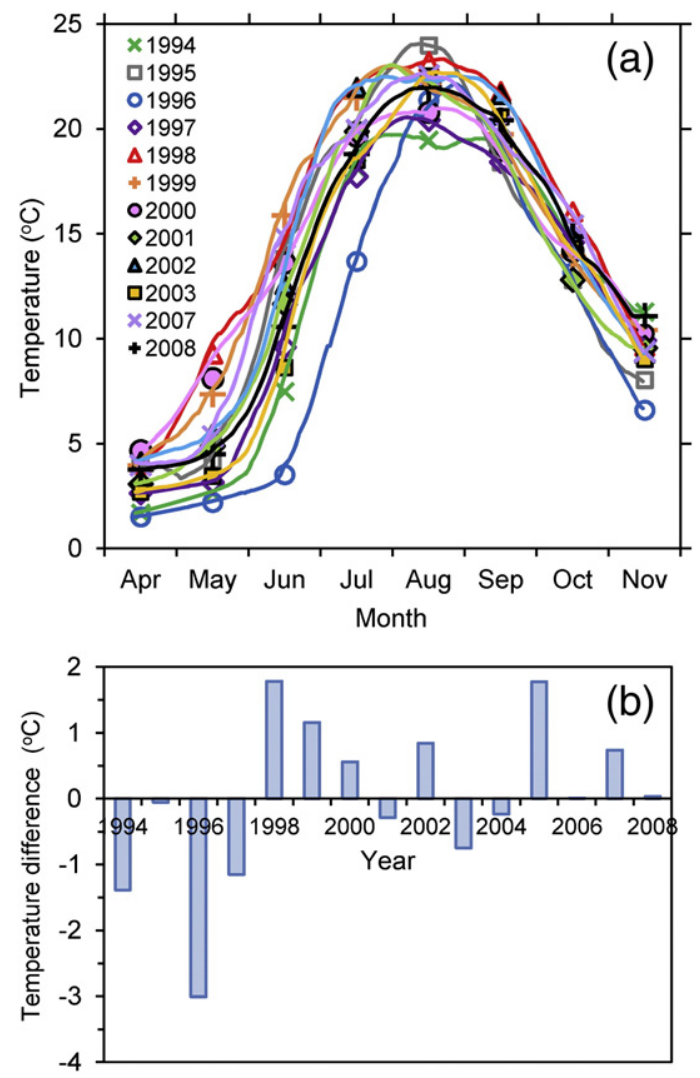

Fig. 1. Seasonal (April-November) thermal cycle for near-surface water 1994-2008 determined at a buoy (NDBC Station 45007) in the center of the southern basin of Lake Michigan: (a) 30-day moving average temperature (lines) with mean monthly average temperature (symbols), and (b) departure of seasonal mean temperature from 15-year mean. 
histories of temperatures over the annual cycle for each year, we plotted up the 30-day moving average of daily mean temperatures (Fig. 1).

Methods for measuring and collecting Chl and TP are described by Fahnenstiel et al. (2010) and Mida et al. (2010), and much of the data presented here are reported by them from a much longer time series; however, it was necessary to recast some of their data and include others not reported by them to create a data set appropriate for evaluating interannual patterns in zooplankton species found in different strata of the water column and dominant in different seasons. They were concerned primarily with the spring isothermal conditions and summer epilimnetic conditions. For understanding patterns of zooplankton over the annual cycle, we looked at summer-autumn Chl concentrations in the epilimnion, metalimnion, hypolimnion, and the integrated water column. As noted by Mida et al. (2010), Chl during the winter-spring isothermal period were collected from 1 to 3 depths. During the stratified period, there were usually 2-4 samples taken from each thermal depth zone (epi-, meta-, and hypolimnion), except 1 or 2 in 1999 and 2000, and one during 2001-2003. An integrated water column value was approximated from the Chl values and thickness of each depth zone from temperature profiles. We also created annual patterns experienced by epilimnetic, metalimnetic, and hypolimnetic zooplankton by adding the summer-autumn results to the results from spring. For example, the $L$. sicilis population (Torke, 1975; Table 1) would first be exposed to spring isothermal conditions, and during summer and autumn, move into the hypolimnion; therefore when looking at the population as a whole, we are interested in approximating the spring, summer, and annual experience of the population. For L. ashlandi, for example, we were interested in the metalimnion dynamics (Table 1).

\section{Analysis of seasonal and interannual patterns}

We looked at the zooplankton data from four perspectives. First, we examined the raw zooplankton time series because these patterns, along with knowledge of the species ecology (Table 1), give insights into what is causing the observed patterns and potential forcing variables. Second, to help visualize seasonal patterns for the individual species, we created box-and-whisker-plots depicting the average, median, and interquartile range for each month aggregated across all years. Third, we compared average "annual" mean zooplankton biomass in different years to look for correlations with Chl and predators to explain interannual variability.

Fourth, to gain further insight into forces driving the annual patterns, we also looked at correlations in different seasons: spring (April-May), summer-autumn (June-November), and autumn (September-November). This allowed us to examine patterns that might be related to loss of the spring bloom and other seasonal phenomena. We note that the summer-autumn season formed a natural period of interest in that many of the "summer species" (particularly the cladocerans and Epischura) life cycles were largely constrained to this stratified period. We reasoned autumn (September-November) biomass of zooplankton would be particularly sensitive to age-0 fish effects since age- 0 fishes would attain their greatest population biomass at this time. In contrast, zooplankton in other seasons might be more sensitive to YAO alewives.

Correlation analysis was used to explore the relationship of zooplankton abundance to potential forcing variables. Correlations were first done between untransformed zooplankton data. If visual examination showed curvilinearity in the relationship, zooplankton data were $\ln$ transformed and correlation coefficients recalculated. Results were considered significant at the $\mathrm{P}<0.05$ level.

Lastly, because the period after 2004 represented the major expansion of quagga mussels into deep water and loss of the spring bloom (Nalepa et al., 2010; Vanderploeg et al., 2010), we directly compared mean zooplankton biomass aggregated over the years
1993-2003 with that for 2007 and 2008. We used a two-sample $t$ test to evaluate differences between the two time periods. We checked equality of variances between time periods, and if they were not significantly different we used a pooled estimate of variance for calculating the result. If variances were unequal, we used the Satterthwaite approximation to appropriately weight the variances (Satterthwaite, 1946). We were also interested in knowing whether variance during the two time periods was the same to examine the possibility that seasonal extremes in abundance differed between the time periods. Results were considered significant if $\mathrm{P}<0.05$, and highly significant if $\mathrm{P}<0.01$.

In some years, sampling intensity was higher in summer months than in spring and autumn months, and vice versa in other years. To remove some of the bias associated with variable frequency within months in calculation of the average annual mean, we first averaged data in a given month and then calculated an average from the monthly mean values. Typically there was good monthly coverage from April to November, but this varied from year to year depending on weather and ship availability. To ensure comparability of annual patterns, we calculated annual means only from the period AprilNovember.

\section{Results and discussion}

\section{Annual thermal cycle and zooplankton time series}

\section{The annual thermal cycle}

Surface or epilimnetic temperatures showed a minimum in April and a maximum occurring between late July and late August; however, there was considerable variation in timing for the setting up of stratification as well as in the annual mean temperatures (Figs. 1a and b). Average May temperatures varied between 2.2 and $9.2^{\circ} \mathrm{C}$, and those for June were between 3.5 and $15.9^{\circ} \mathrm{C}$. During the cold winter and spring of 1996 , surface temperature did not reach $5{ }^{\circ} \mathrm{C}$-the temperature indicating incipient stratification-until late June, whereas in 1998-2000, $5{ }^{\circ} \mathrm{C}$ was reached by late April (Fig. 1a). The period 1994-1997 represents a run of below or average annual temperatures, with 1994, 1996, and 1997 showing strong negative deviations from the 15-year annual mean. The period 1998-2000 represents a 3-year run of above-average temperatures. Overall, 1996 shows up as the coldest year and 1998 as the warmest year over the years sampled (Fig. 1b).

\section{Seasonal and long-term time trends in zooplankton}

Seasonal patterns of zooplankton across species and years are shown in Figs. 2, 3 and 5, 6; corresponding patterns for overall abundance of within each month averaged across all years is shown in Figs. 4 and 7. Mesozooplankton community biomass (mg dry weight $/ \mathrm{m}^{3}$ ) exhibited a consistent seasonal pattern among years showing a maximum in mid or late summer (Figs. 2a and 4a), the time of maximum water temperature, with similar maximum values in most years; however, there were 3 years $(1999,2007,2008)$ in which the summer maximum was greatly diminished (Fig. 2a). Biomass was also very low in spring 1999, reflecting low values seen in autumn 1998. Average annual zooplankton biomass was at a minimum during 1999 (Fig. 2a).

Timing of the zooplankton biomass maximum varied among years, and the coldest year in 1996 and fast spring warm-up in 1998 provide an interesting contrast. Peak biomass (Fig. 2a) was observed at day 190 in 1998 and at day 270 in 1996 . The results for 2007 and 2008 are different from other years in that biomass was relatively low and flat across seasons. Not only were there no marked summer maxima, there were no marked spring and autumn minima. This trend is statistically supported by the observation that variance of monthly averaged biomass post-quagga expansion (2007-2008) was lower than that for the pre-expansion period (1994-2003) (Table 2). Although mean of monthly averaged biomass was lower after the quagga expansion 

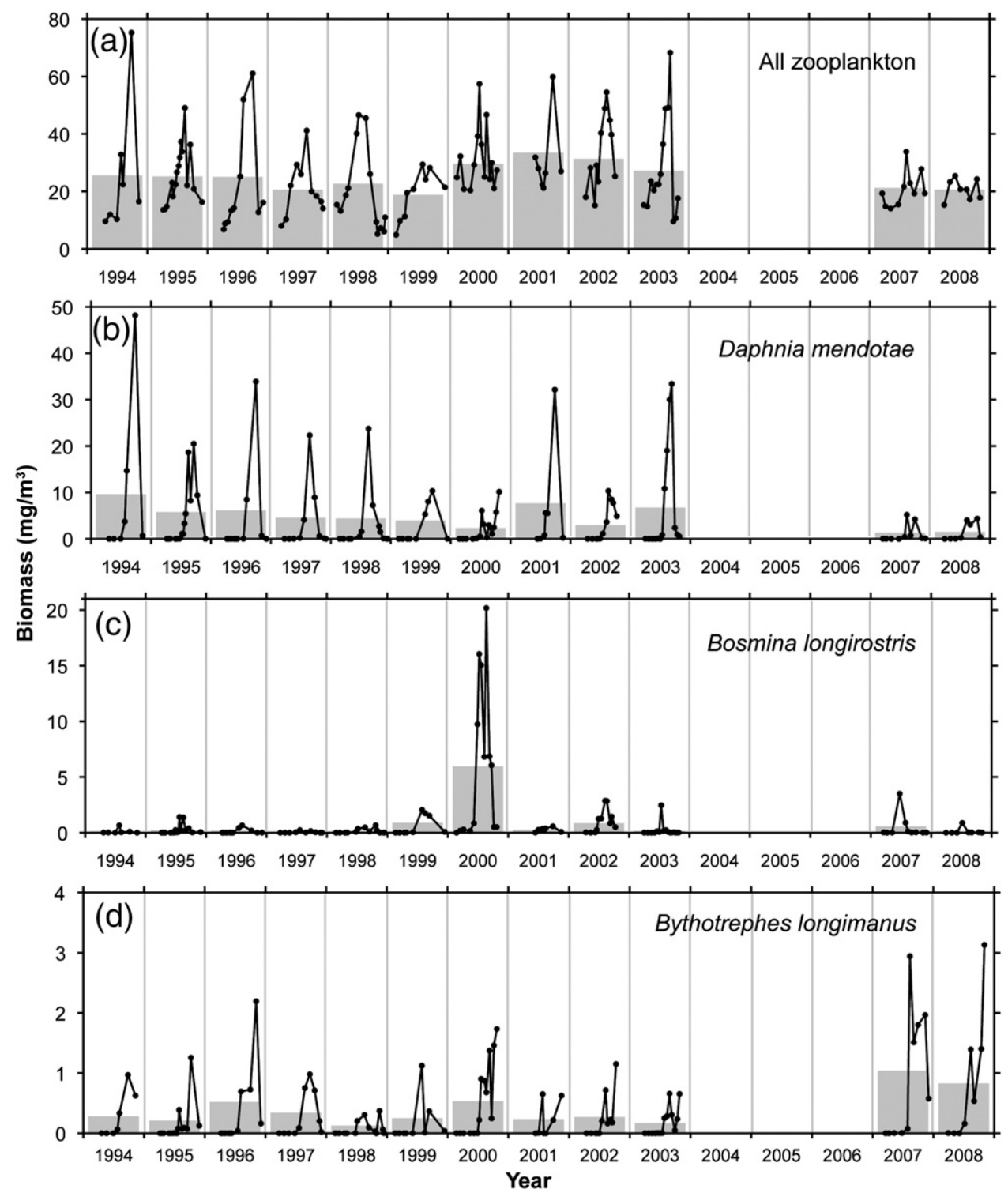

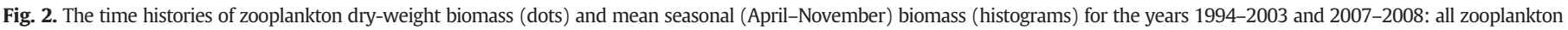

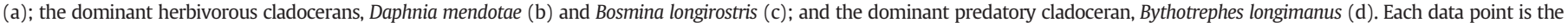
mean of duplicate tows, and seasonal mean biomasses were calculated from means of monthly data.

than before the expansion ( 20.9 vs. $27.0 \mathrm{mg} / \mathrm{L}$; Table 2), minimum annual biomass occurred in 1999 (Fig. 2). This minimum was strongly influenced by low spring concentrations that were a continuation of low values first seen in autumn 1998.

There were considerable differences, however, among the time series for different species. The herbivorous and predatory cladocerans were important components of the summer and autumn zooplankton. Herbivorous cladocerans Bosmina longirostris and Daphnia mendotae, peaking in summer and late summer-early autumn respectively, showed high variation among years, and abundance of this group was lowest in 2007 and 2008 (Figs. 2 and 4, Table 2). Daphnia was a major contributor to the summer-autumn peak in zooplankton abundance during the pre-quagga expansion period (Figs. $2 \mathrm{~b}$ and $4 \mathrm{~b}$ ), although its annual \% biomass contribution was relatively low (20.3\%; Table 2). Although generally low in abundance throughout the study period (3.3\% of zooplankton biomass), Bosmina showed a large peak in 2000 (Fig. 2c). Interestingly, Daphnia concentration was relatively low in 2000 , so that the aggregate abundance of herbivorous cladocerans (not shown) in 2000 fell into the mid range of values. The mean concentration of Daphnia and the aggregate of Daphnia plus Bosmina were significantly lower in the post- expansion period (Table 2): the aggregate biomass of this herbivorous cladoceran group (Table 2) decreased from 23.4 to $8.5 \%$.

Bythotrephes longimanus, the largest zooplankter in Lake Michigan (Table 1), occurred throughout summer and fall with highest abundance occurring in November (Figs. 2d and 4d). Bythotrephes biomass was fairly stable among years during 1994-2003 but showed high mean values in 1996, 2000, 2007, and 2008 and very low values in 1998 and 2003 (Fig. 2d). Post expansion abundance showed a significant $210 \%$ increase relative to the pre-expansion period (Table 2). Consequently, the percentage of Bythotrephes biomass relative to its preferred prey (combined herbivorous cladocerans) increased from 5\% in 1994-2003 to 52\% in 2007-2008 (Tables 1 and 2).

Diaptomid (Leptodiaptomus spp.) copepods, all omnivores (Table 1), were the dominant calanoid, having high peak biomass, high annual average biomass, and presence throughout the year as copepodites and adults (Figs. $3 \mathrm{a}$ and $\mathrm{b}$ and $4 \mathrm{e}$ and $\mathrm{f}$ ); they represented 49 and $57 \%$ of the overall annual biomass during pre- and post-expansion periods, respectively (Table 2). Annual abundance was evenly split between copepodites and adults (histograms in Fig. 4). Diaptomid copepodite abundance peaked out in early 

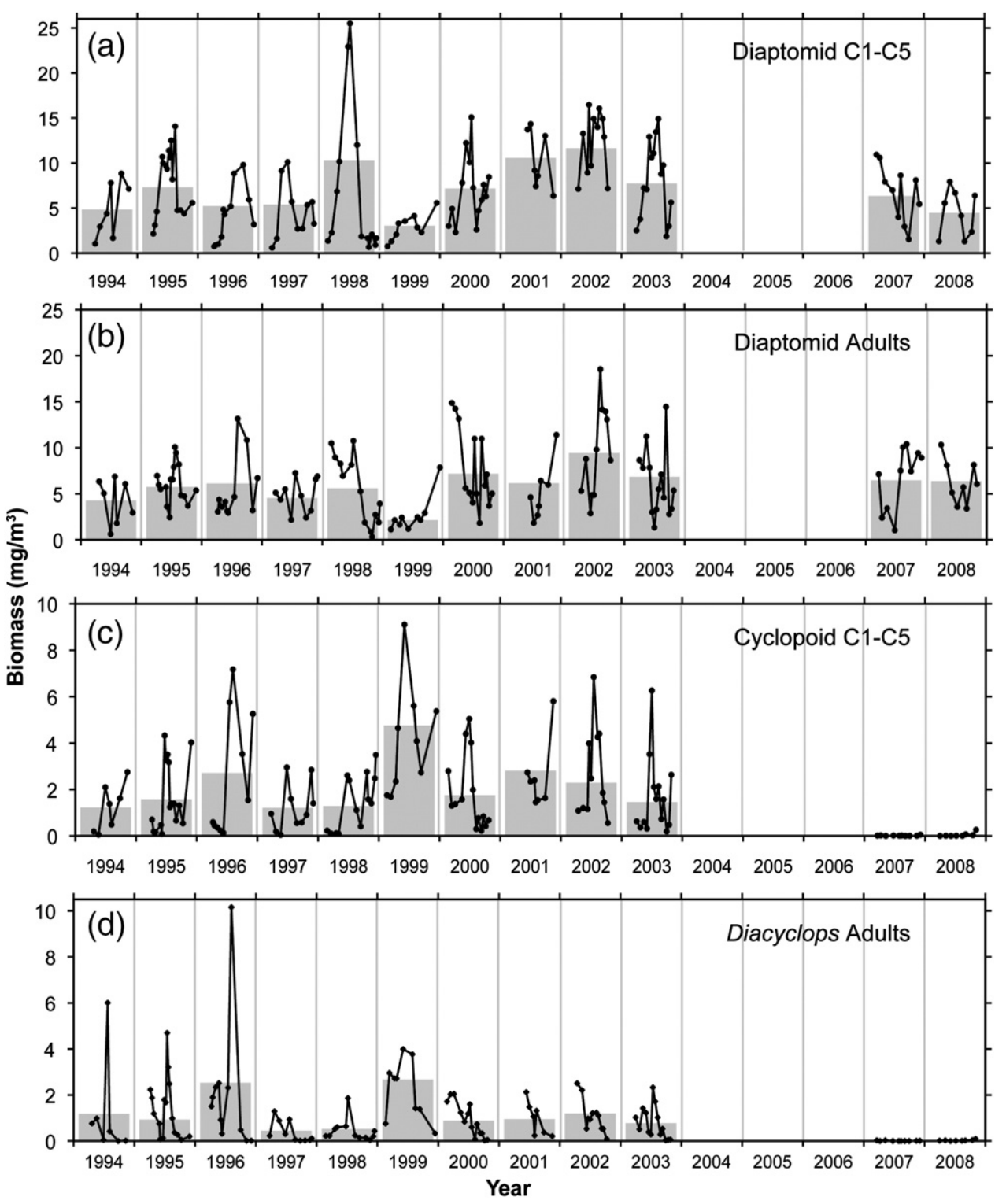

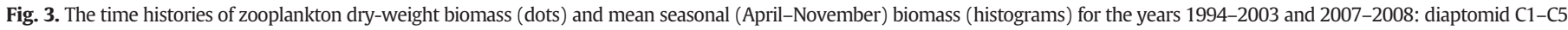

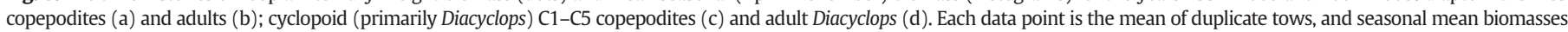
were calculated from means of monthly data.

summer, and the adults had a relatively even abundance across months (Figs. 4e and f). The autumn of 1998 and all of 1999 stand out in great contrast to all other years in that biomass of diaptomids -both copepodites and adults-fell to extremely low levels in fall 1998 that continued into autumn 1999 (Figs. 3a and b). The extreme drop in the diaptomids is the reason for the low concentration observed for total zooplankton (Fig. 2a).

Adults of the different species of Leptodiaptomus showed markedly different seasonal and interannual patterns, so some individual species patterns departed from the aggregate response of the group (Figs. 5 and 7). Adult L. minutus, the epilimnetic and least abundant species, showed uniformly low values except in 2000 (Table 1; Fig. 5b); mean biomass during the post-expansion period showed a highly significant decrease (by 56\%) relative to that during the preexpansion period (Table 2). Adults of this species tended to peak in winter and spring (7b).

Biomass of $L$. ashlandi, the metalimnetic and most abundant diaptomid species during the pre-expansion period, was highly variable from year to year (Tables 1 and 2, Fig. 5c). On average, adults maintained high biomass levels late winter through summer (Fig. 7c); biomass showed a significant decrease (45\%) during the postexpansion period (Table 2).

The hypolimnetic Leptodiaptomus sicilis, like the aggregate response of the group showed extremely low minimum biomass values in 1999, but unlike the other two species showed an increase in biomass starting in 2000 that continued into 2007 and 2008 (Tables 1 and 2; Fig. 5). Although present as adults throughout the year, L. sicilis had highest biomass during autumn (Fig. 7d). In marked contrast to the other diaptomid species, $L$. sicilis showed a highly significant increase (86\%) during the post expansion period. As a result of these changes, L. sicilis became the dominant diaptomid in 2007-2008, representing $22.4 \%$ of total zooplankton biomass (Table 2 ).

The cyclopoid group was dominated by the microzooplankton predator Diacyclops and the biomass patterns shown are for Diacyclops copepodites and adults (Table 1, Figs. $3 \mathrm{c}$ and $\mathrm{d}$ and $4 \mathrm{~g}$ and $\mathrm{h}$ ). Diacyclops copepodites abundance tended to peak from summer through autumn, following the adults that were most abundant in spring and early summer (Figs. $4 \mathrm{~g}$ and $\mathrm{h}$ ), and population biomass varied greatly among years (Fig. 4). During the pre-expansion period, they represented a modest component of average total community 

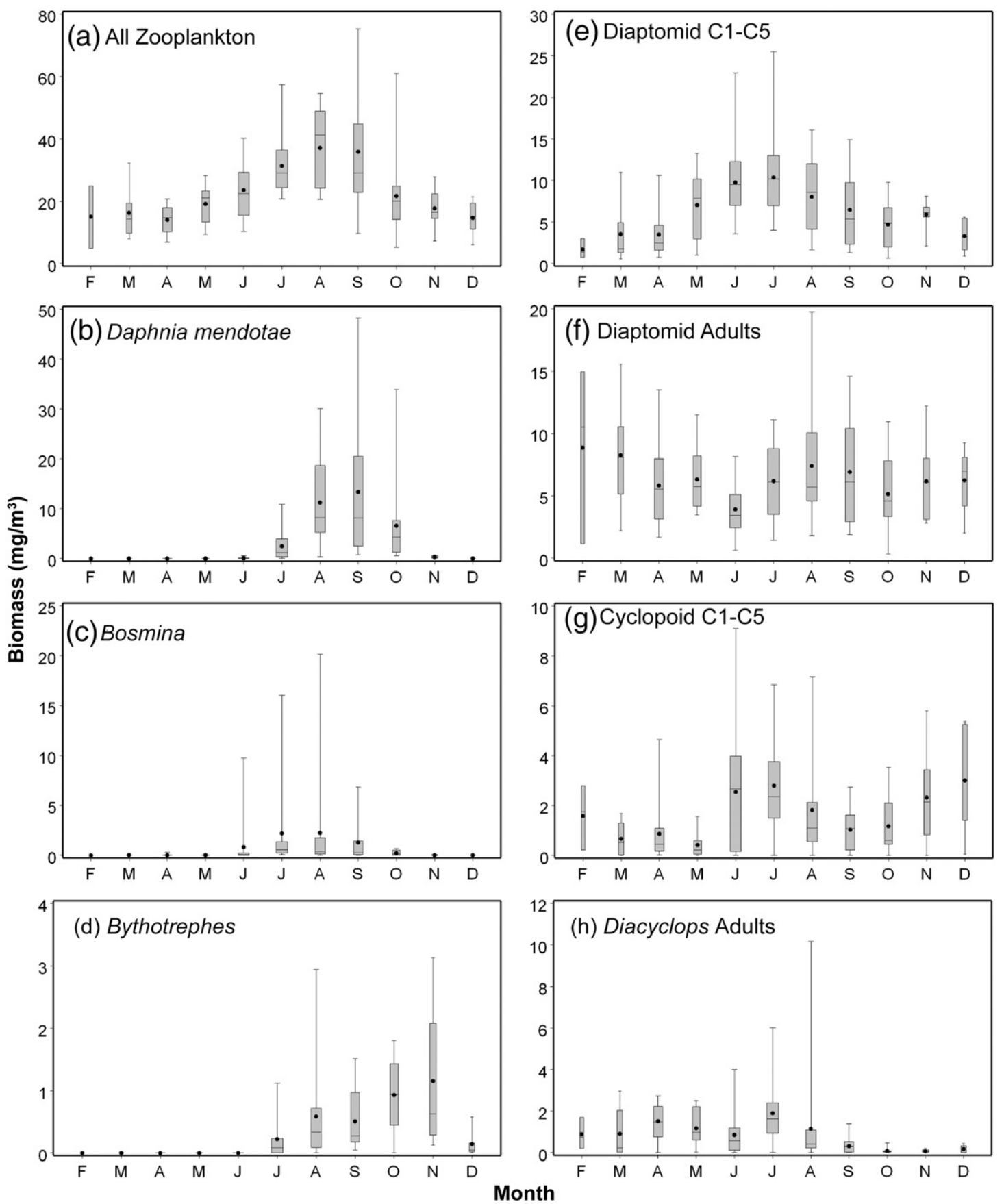

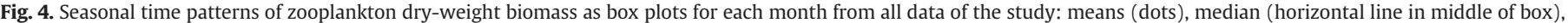

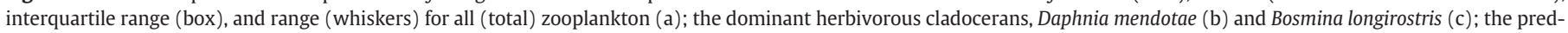

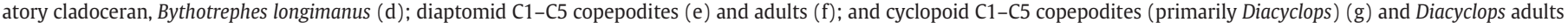
(h). Width of the box is proportional to number of samples collected for that month.

biomass (11.8\%, Table 2$)$; during the post-expansion period, the population collapsed.

Copepod nauplii biomass tended to peak in the spring (Fig. 7a), matching an expected major reproductive period of diaptomids in spring and preceding the increase of $\mathrm{C} 1-\mathrm{C} 5$ diaptomids in late spring and early summer (Fig. 4e). Maximum biomass and mean biomass were extremely variable from year to year, with 1994, 1997, 2007, and 2008 showing the lowest average values (Fig. 5a). The average value for the post-expansion period was significantly lower with a $62 \%$ decrease relative to the preexpansion period. Note that because of the relatively coarse mesh size of the net we used, nauplii would be undersampled, especially for the smallest species such as L. minutus and Diacyclops. The abundance of Diacyclops adults in early summer and abundance of their copepodites during fall suggest we may have missed capturing Diacyclops nauplii during summer; likewise we may have missed capturing nauplii of $L$. minutus and even some $L$. ashlandi in summer and fall, considering that adults were abundant throughout spring and summer.

Predatory calanoid copepods showed considerable variability among years, but both had relatively high peaks and high mean biomass in 2007 and 2008 that were significantly higher than in 19942003 (Tables 1and 2; Fig. 6). Limnocalanus macrurus, the larger predatory calanoid, occurred as copepodites during the spring and adults throughout the rest of the year, with adult biomass peaking in summer and fall (Table 1; Figs. 7e and f). Limnocalanus biomass was variable among years (Fig. 6), with 2008, 1997, and 2007, being respectively the first through third highest years, and 1998 the 

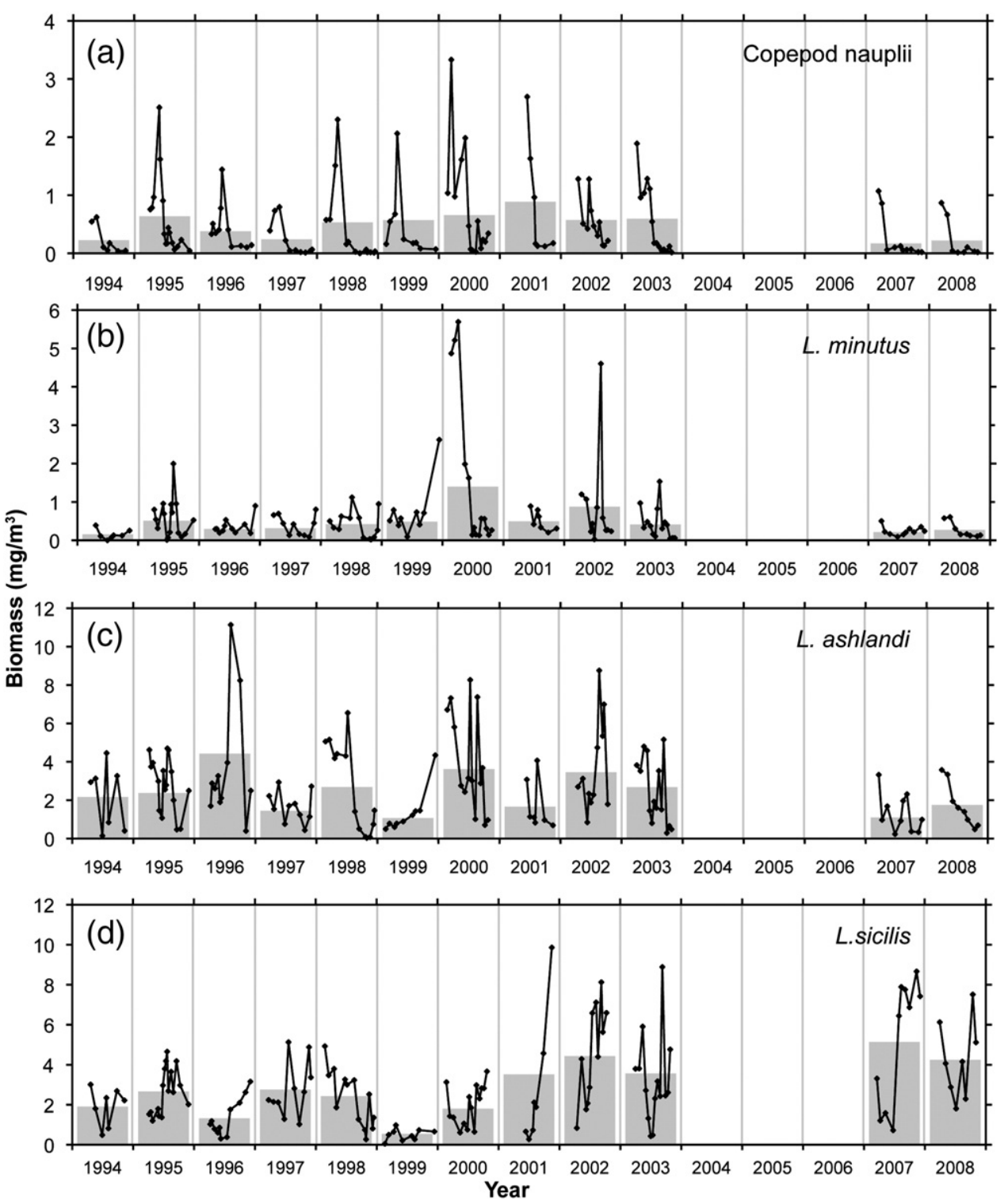

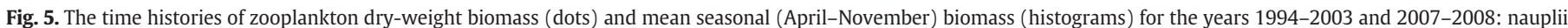

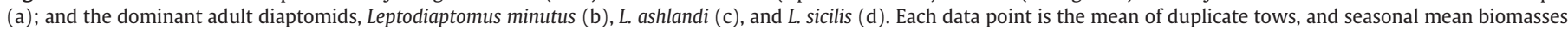
were calculated from means of monthly data.

lowest. Averaging across years, Limnocalanus abundance during the post-expansion period was significantly higher than in the preexpansion period of mussels. Limnocalanus (adults and juveniles) became the dominant zooplankton species (27\% of total biomass; Table 2); however, if $L$. sicilis $C 1-C 5$ stages could have been identified, it might have taken this role.

Biomass of copepodites and adults of Epischura lacustris, a medium-size calanoid predator and least abundant zooplankter considered in our study, peaked during the summer and autumn and increased in the later years of the study; their biomass was significantly higher during the post-expansion period (Tables 1 and 2; Figs. 6 and 7). Like many other calanoids, it was least abundant during 1999.

\section{Driving variables and their changes}

There were considerable changes in some potential driving variables over the study period. Water column Chl results are shown as box-and-whisker plots for concentrations each month for the whole study (Fig. 8a) as well time histories for water-column Chl spring (March-May) (Fig. 8b) and summer-autumn (June-December) Chl for the water column (Fig. 8c) and metalimnion (8d). Complete time histories for the epilimnion can be found in Mida et al. (2010). Mean Secchi depths and concentrations of Chl and TP during the pre- and post-expansion periods can be found in Table 3. Abundances of the main vertebrate predators, YAO alewife biomass and year class strength, are shown in Fig. 9.

Over the study period, spring and early summer (April through July) were important periods of high water column Chl (Fig. 8a). However, average water column values decreased markedly during spring in 2003 and in 2007-2008 (Fig. 8b); in contrast, changes in summer-autumn were not as pronounced (Fig. 8c). Comparing the pre- and post-expansion period, Chl was significantly lower by $65 \%$ during spring but not significantly lower during summer-autumn (Table 3). There were no appreciable or significant changes in the epilimnetic Chl (see complete time series in Mida et al., 2010) nor in the hypolimnetic Chl; however, there was a large (41\%), significant decrease in the summer-autumn metalimnetic Chl (Table 3, Fig. 8d). Note water column TP decreased by $31 \%$ in spring and $24 \%$ in summer-autumn (Table 3). Secchi depth was relatively constant over the pre-expansion period (Vanderploeg, unpublished data) and 

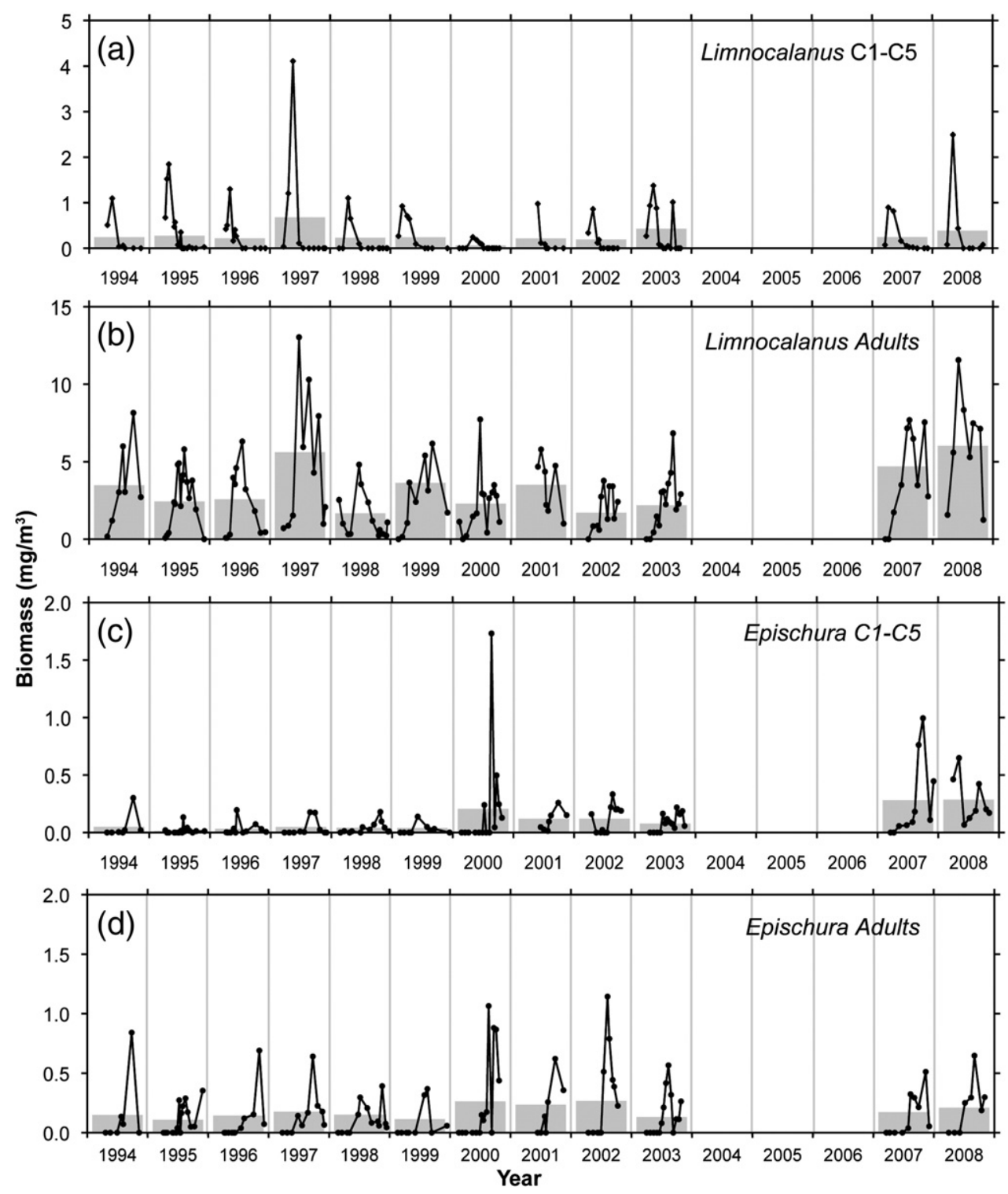

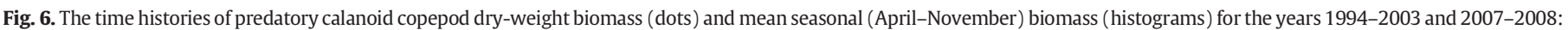

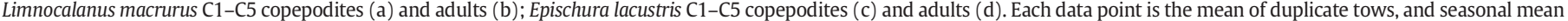
biomasses were calculated from means of monthly data.

greatly increased during the post-expansion period (Table 3), with increases of $110 \%$ during spring and $52 \%$ during summer-autumn.

Over the study period, there was considerable inter-annual variation in age- 0 alewives, age- 1 index, and YAO alewives captured in the trawl. Overall, YAO alewife abundance was highly variable $(\sim 2-$ $14 \mathrm{~kg} / \mathrm{ha}$ ) but without trend between 1994 and 2003 (Fig. 9). Highest age-0 alewife abundance was seen in 1998. No age-0 index values were available for 2008; however, acoustic data revealed that age0 alewife biomass density was relatively low for that year (Warner et al., 2009). Note that although no trawl data were available for 1998 , it is likely there was a large population of adult alewives then to produce the large class.

\section{Analysis-biotic factors}

Table 4 shows all significant correlations for zooplankton biomass with all potential forcing variables, including large predatory zooplankton, in different seasons. Despite some large changes in Chl in some depth zones and seasons, correlation analysis suggested only a few taxa were sensitive to Chl concentration and only during the summer-autumn. Average summer-autumn biomass of Bosmina+Daphnia,
Daphnia, and total zooplankton were significantly positively correlated with metalimnetic Chl; nauplii were negatively correlated with epilimnetic Chl (Table 4). Despite the large decrease in Diacyclops in 20072008, correlation analysis did not show evidence for an effect of Chl.

The extreme drop in total zooplankton biomass during autumn of 1998 , the lowest observed value in spring 1999, and the lack of a midsummer peak in 1999 (Fig. 2) are qualitatively consistent with the extremely high biomass (and planktivory) of age-0 alewives in 1998 and age-1 alewives in 1999 (Fig. 9). This is also borne out by the correlation analysis; over the time period 1994-2003 and 2007 (the time period alewife data are available), average autumn calanoid (sum of diaptomids, Epischura, and Limnocalanus) copepods and total zooplankton biomasses were significantly negatively correlated with age-0 alewives (Table 4). Significant negative correlations with age1 alewives were found for calanoids and diaptomids during spring and summer and for calanoids, diaptomids, and L. sicilis over the annual cycle (Table 4). These correlations were strongly influenced by the 1998 and 1999 data. Conversely, biomass of C1-C5 cyclopoids and cyclopoids were positively correlated with age- 1 alewives during spring; cyclopoid adults, cyclopoids, and C1-C5 cyclopoids were 

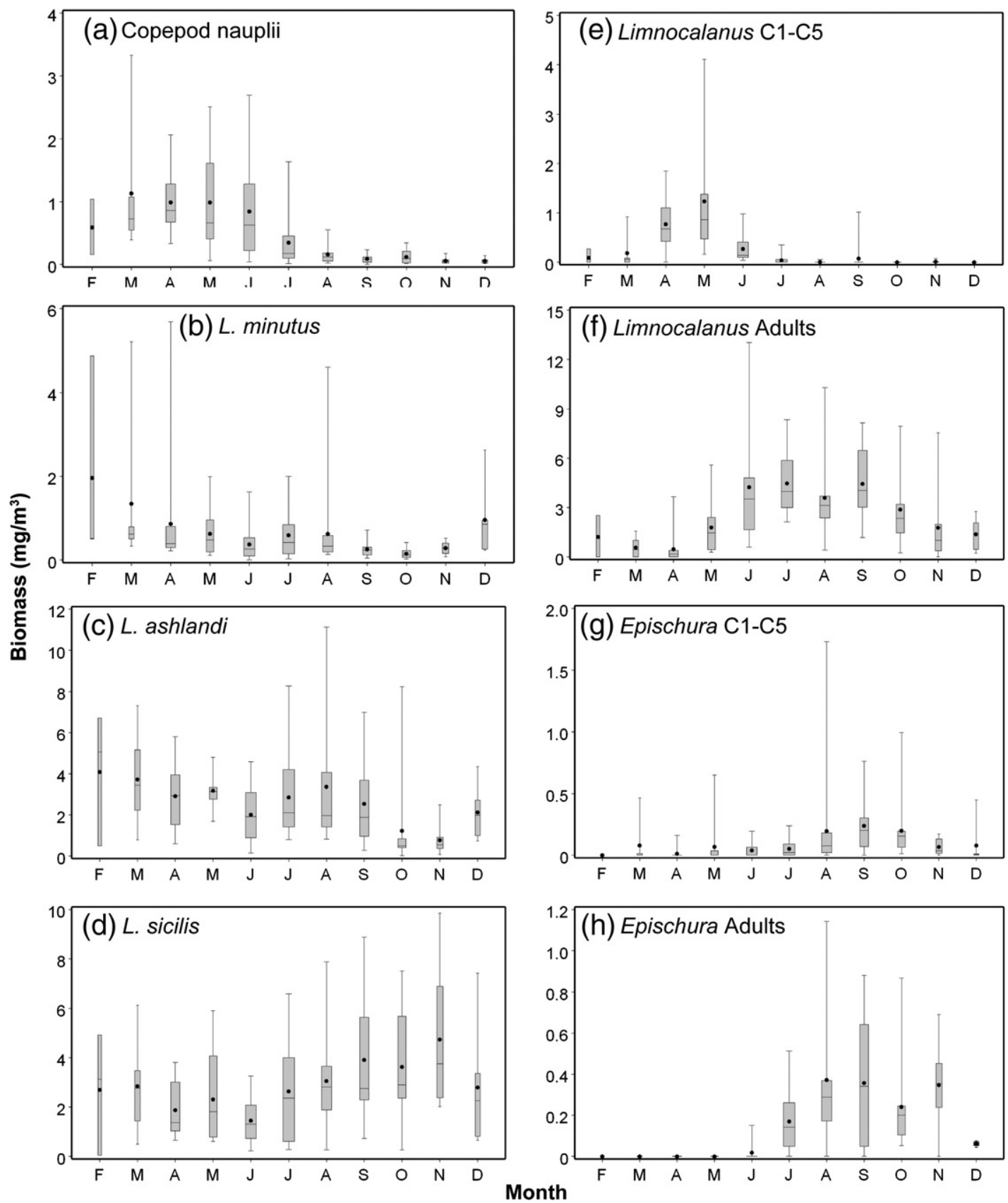

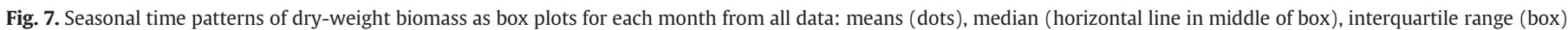

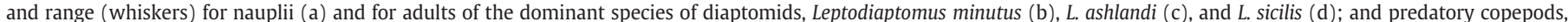

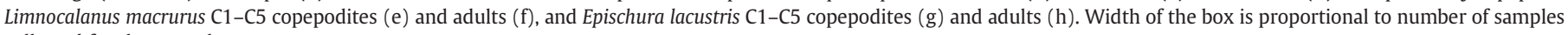
collected for that month.

positively correlated with age-1 alewives during summer-autumn and over the annual cycle.

As expected from the high feeding preference of YAO alewives for Bythotrephes, Bythotrephes abundance over the whole period of the study (1994 to 2008) was negatively correlated with YAO alewives. That the lowest biomass of Bythotrephes occurred in 1998, the year of the large age-class of alewives, may be related to the early start this age class got with warm spring temperatures. By autumn, the abundant age- 0 fish could have been relatively large and could have exerted high mortality on Bythotrephes. Also, the increased temperature would have increased consumptive needs of the fish. It is also possible that there was a large population of adults that year necessary to create the strong year class in the first place. These YAO fish may have had an impact too.
Correlation analysis gave evidence of invertebrate predation by Bythotrephes and Limnocalanus. As expected from the prey preference of Bythotrephes for cladocerans (Table 1), a significant negative correlation was found for Daphnia (Table 4). Significant negative correlations for total zooplankton, nauplii, diaptomids C1-C5, L. ashlandi, and diaptomids were found with adult Limnocalanus or Limnocalanus during spring-autumn or summer-autumn. This is consistent with predatory feeding habits of Limnocalanus (Table 1) and spatial and temporal overlap during the winter-spring transition (Table 1).

The flat (lacking peaks and troughs) aspect of the seasonal data for total zooplankton for 2007 and 2008 is consistent with relaxed fish predation and increased predation from Bythotrephes. Bythotrephes, by removing Daphnia during the late summer-early autumn, would be removing the summer-autumn peak, since Daphnia was a major 
Table 2

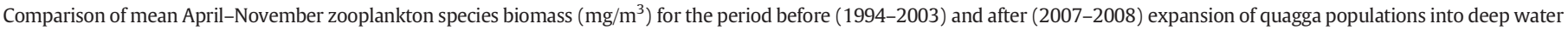

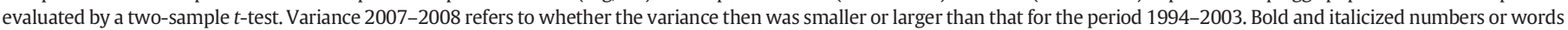

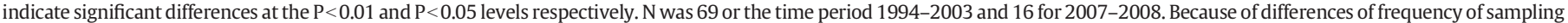
within a given month in different seasons and years, mean monthly values were used for all calculations.

\begin{tabular}{|c|c|c|c|c|c|c|}
\hline \multirow[t]{2}{*}{ Variable } & \multicolumn{2}{|c|}{ Biomass before } & \multicolumn{2}{|c|}{ Biomass after } & \multirow{2}{*}{$\begin{array}{l}\text { Variance } \\
2007-2008\end{array}$} & \multirow{2}{*}{$\begin{array}{l}\text { Change } \\
(\%)\end{array}$} \\
\hline & Mean & $\%$ & Mean & $\%$ & & \\
\hline Total zooplankton & 27.05 & 100.00 & 20.92 & 100.00 & Smaller & -22.66 \\
\hline Daphnia mendotae & 5.42 & 20.3 & 1.43 & 6.83 & Smaller & -73.62 \\
\hline Bosmina longirostris & 0.89 & 3.29 & 0.35 & 1.66 & Smaller & -60.67 \\
\hline Daphnia plus Bosmina & 6.32 & 23.36 & 1.78 & 8.49 & Smaller & -71.83 \\
\hline Diaptomids (C1-C6) & 13.25 & 48.98 & 11.82 & 56.51 & Smaller & -10.79 \\
\hline Cyclopoids (Diacyclops C1-C6) & 3.18 & 11.76 & 0.057 & 0.27 & Smaller & -98.21 \\
\hline Copepod nauplii & 0.50 & 1.85 & 0.19 & 0.93 & Smaller & -62.00 \\
\hline Leptodiaptomus minutus & 0.54 & 2.00 & 0.24 & 1.16 & Smaller & -55.55 \\
\hline L. ashlandi & 2.61 & 9.65 & 1.43 & 6.81 & Smaller & -45.21 \\
\hline L. sicilis & 2.52 & 9.32 & 4.69 & 22.44 & Larger & +86.11 \\
\hline Epischura lacustris (C1-C6) & 0.25 & 0.92 & 0.48 & 2.27 & Same & +92.00 \\
\hline Limnocalanus macrurus (C1-C6) & 3.18 & 11.76 & 5.68 & 27.14 & Same & +78.62 \\
\hline All calanoids & 16.70 & 61.74 & 18.03 & 86.36 & Same & +7.96 \\
\hline Bythotrephes longimanus & 0.30 & 1.11 & 0.93 & 4.46 & Larger & +210.00 \\
\hline
\end{tabular}

contributor to the summer-autumn peak during pre-expansion years. Food limitation also could have been a factor as well since Daphnia was positively correlated with metalimnetic Chl. Contrast this with very low zooplankton biomass in autumn 1998 and spring 1999, when fish predation was likely very high. Fish predation by driving down overwintering populations of copepods during the autumn would have a marked effect during spring as well.

\section{Analysis-abiotic factors}

Phenology of zooplankton succession was affected by onset of stratification (as noted above), and correlation analysis showed that spring abundance of zooplankton and nauplii were significantly correlated with mean spring water temperature. However, a lack of significant correlations over the annual cycle or in other seasons suggested that epilimnetic temperature was not an important factor in determining annual changes in zooplankton abundance despite wide swings in temperature over the study period.

Correlation analysis suggested that Secchi depth was a potentially important factor affecting zooplankton abundance. Bythotrephes, Epischura C1-C5, and L. sicilis abundances were positively correlated with summer-autumn Secchi depth, whereas negative correlations were found for Bosmina + Daphnia and Daphnia (Table 4). The negative correlation between Secchi depth and Daphnia + Bosmina biomass may reflect food limitation because of the expected inverse relationship between algal abundance (and other particulate matter) and Secchi depth. However, the strong correlation of Bythotrephes biomass with Secchi depth is consistent with increased foraging efficiency associated with increased light levels. Bythotrephes is particularly sensitive to light intensity since its threshold for visual planktivory is much higher than that for fish $\left(\sim 3 \mathrm{vs} .0 .2 \mu \mathrm{mol} / \mathrm{m}^{2} / \mathrm{s}\right.$ in 400-700 nm range) (Muirhead and Sprules, 2003; Vanderploeg
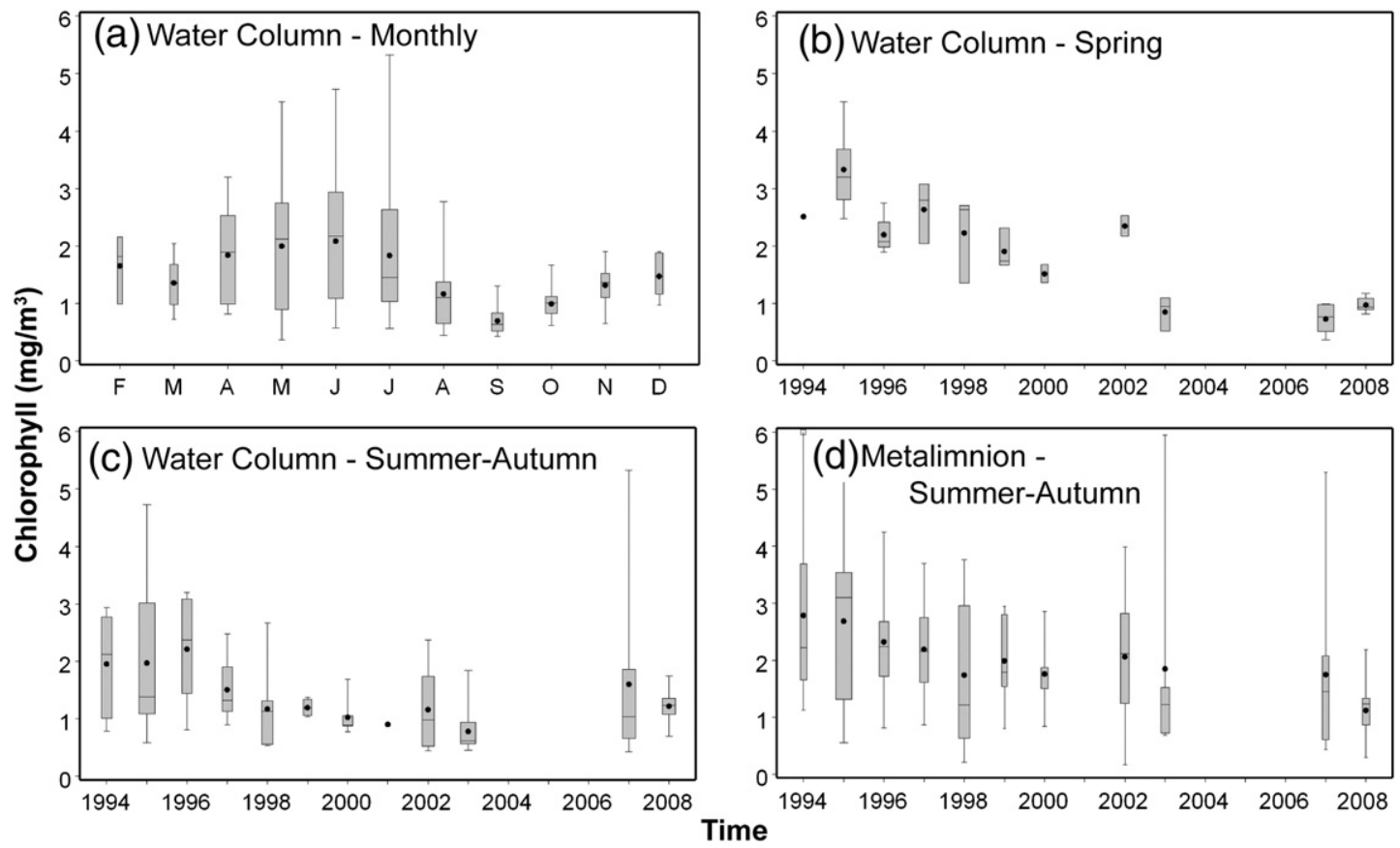

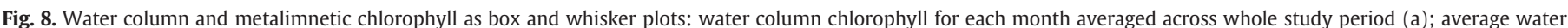

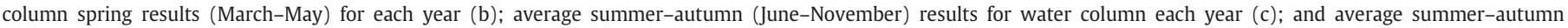

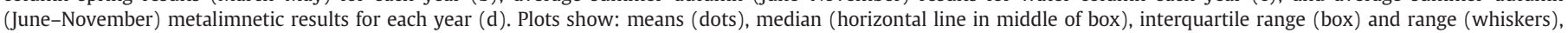
with width proportional to number of data points. 
Table 3

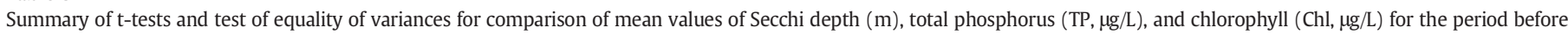

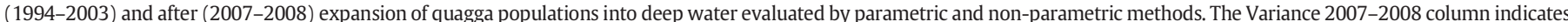

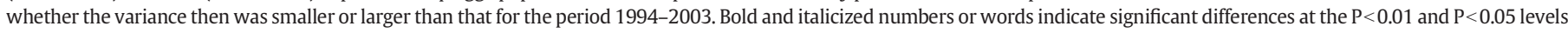
respectively. $\mathrm{N}$ is the number of monthly values that went into calculation of mean.

\begin{tabular}{|c|c|c|c|c|}
\hline \multirow[t]{2}{*}{ Variable } & \multicolumn{2}{|l|}{ Mean $(\mathrm{N})$} & \multirow{2}{*}{$\begin{array}{l}\text { Variance } \\
2007-2008\end{array}$} & \multirow{2}{*}{$\begin{array}{l}\text { Change } \\
(\%)\end{array}$} \\
\hline & Before & After & & \\
\hline Secchi-spring (Apr-May) & $6.89(14)$ & $14.50(4)$ & Larger & +110.45 \\
\hline Secchi-summer-autumn (June-Nov) & $7.62(43)$ & $11.62(8)$ & Same & +52.49 \\
\hline Secchi-annual (Apr-Nov) & $7.45(53)$ & $12.50(12)$ & Same & +67.79 \\
\hline Water column TP-spring (Apr-May) & $5.30(22)$ & $3.65(9)$ & Same & -31.13 \\
\hline Water column TP-summer-autumn (Jun-Nov) & $5.06(47)$ & $3.85(10)$ & Same & -23.91 \\
\hline Water column TP-annual (Apr-Nov) & $5.15(63)$ & $3.88(15)$ & Same & -24.66 \\
\hline Water column Chl-spring (Apr-May) & $2.36(22)$ & $0.83(9)$ & Smaller & -64.83 \\
\hline Water column Chl-summer-autumn (Jun-Nov) & $1.41(49)$ & $1.28(12)$ & Same & -9.22 \\
\hline Water column Chl-annual (Apr-Nov) & $1.62(64)$ & $1.16(17)$ & Same & -28.40 \\
\hline Epilimnetic Chl-summer-autumn (Jun-Nov) & $1.65(49)$ & $1.44(12)$ & Same & -12.73 \\
\hline Metalimnetic Chl-summer-autumn (June-Nov) & $2.09(48)$ & $1.24(12)$ & Same & -40.67 \\
\hline Hypolimnetic Chl-summer-autumn (Jun-Nov) & $1.08(48)$ & $1.20(12)$ & Same & +11.11 \\
\hline
\end{tabular}

et al., 2009); therefore, the water clarity increase would have greater significance for Bythotrephes than fish in the upper water column, where Bythotrephes resides. Increased foraging efficiency and biomass would put stress on both Bosmina and Daphnia directly and indirectly by inducing DVM of the prey into deeper suboptimal areas (cooler) of the hypolimnion (Pangle and Peacor, 2006). Therefore the correlation with increased light operating through the mechanism of increased visual predation is consistent both with an increase in Bythotrephes biomass and decreases in Daphnia and Bosmina biomass. However, we cannot point to such a mechanism for the positive correlation for Epischura C1-C5 and L. sicilis.

\section{General discussion}

\section{Complex interactions}

For the first time, a decadal seasonal time series of crustacean zooplankton has been obtained for full water column tows of crustacean zooplankton in offshore Lake Michigan. As far as we are aware, no such full water column-time series have ever been obtained before for any Laurentian Great Lake. These results were obtained for a period that included a critical ecosystem transition. Putting things in the perspective of broad taxonomic categories, there was an overall shift in the importance of calanoids over cladocerans and cyclopoids from pre- to post-expansion periods of quagga mussels. Overall, calanoids increased in percent composition from 60.7 to $86.4 \%$; herbivorous cladocerans decreased from 23.4 to $8.5 \%$ and cyclopoids from 11.6 to $0.1 \%$.

However, the changes in individual species and causes thereof were complex and cannot be explained by simple generalities of broad taxonomic categories. What is immediately obvious from Table 1 is that each of the species has a distinct niche in terms of its size, habitat preference, feeding mode, and ability to escape vertebrate and invertebrate predators as well as seasonal timing of populations. Moreover, Torke (1975) noted distinct and different reproductive patterns. Timing of adults and copepodites gave some indications of broad aspects of reproductive patterns. The most similar species Leptodiaptomus spp., in terms of taxonomic closeness and feeding mode (e.g., Bundy et al., 1998), are of different size and have different habitat (depth) preferences (Table 1) as well as size preferences for prey (Vanderploeg, 1994; Vanderploeg et al., 1988) and reproductive patterns (Torke, 1975). Although all diaptomids reproduce during the winter-spring transition, $L$. minutus and $L$. ashlandi have two generations per year. The timing of seasonal patterns for the species present now is very similar to those described in the 15-month detailed study in 1973-1974 by Torke (1975), particularly for 1994-2003. All these details come into play when considering individual species as well as broad taxonomic responses to bottom-up and top-down factors.

The seasonal pattern of $\mathrm{Chl}$ concentration has changed. The relative seasonal patterns of Chl 1994-2003 were similar to those observed by Brooks and Torke (1977) in 1973-1974; spring and early summer were periods of highest water column Chl. In 2007-2008, the importance of the spring phytoplankton bloom had greatly diminished. Over the last two decades, there has been a gradual decline in P loading and TP concentrations in the lake (Mida et al., 2010). The rapid decrease in Chl in the last years of the study would be consistent with mussel filtering and engineering impacts superimposed on a lesser constraint of $\mathrm{P}$ limitation associated with a gradual decline in P loading over the last 20 years (Mida et al., 2010). The changes in Chl were also reflected in large decrease in primary production (Fahnenstiel et al., 2010).

The major increase in water clarity also underscores the dominance of mussel influence during their population expansion and filtering impact, which occurred mostly after 2004.

In addition to the expected stress put on the zooplankton community from loss of the phytoplankton resource base, there was a shift to large predacious species that would put stress on the zooplankton community as well. We documented a decrease in total zooplankton biomass from $26.9 \mathrm{mg} / \mathrm{m}^{3}$ during $1994-2003$ to $20.9 \mathrm{mg} / \mathrm{m}^{3}$ during 2007-2008, representing a decrease of $23 \%$ (Table 2). However, the biomass of predaceous zooplankton (Limnocalanus macrurus, Epischura lacustris, and Bythotrephes longimanus) actually increased from $3.7 \mathrm{mg} / \mathrm{m}^{3}$ during 1994-2003 to $7.1 \mathrm{mg} / \mathrm{m}^{3}$ during 2007-2008. Predaceous zooplankton represent a higher trophic level than the other zooplankton taxa, and the growth efficiency of predaceous

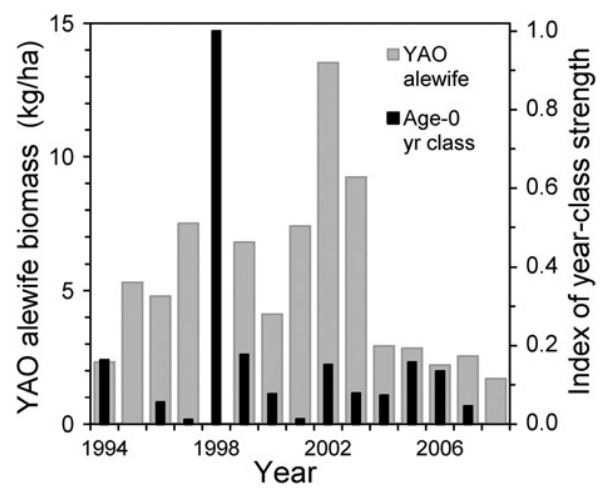

Fig. 9. Yearling and older (YAO) alewife biomass and age- 0 year-class strength of alewives in Lake Michigan determined in annual fall trawl surveys made by the U.S. Geological Survey, Great Lakes Science Center. The lack of histograms in a given year indicates no results are available for that year; see text for details. 
Table 4

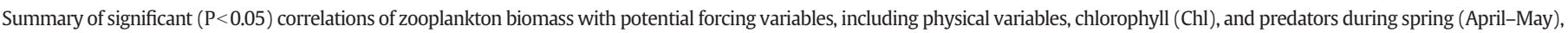

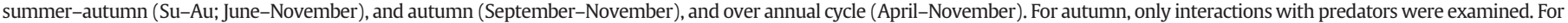

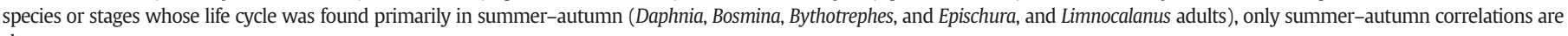
shown.

\begin{tabular}{|c|c|c|}
\hline Season & Forcing variable $(\mathrm{N})$ & Zooplankton correlation coefficients (r) \\
\hline \multirow[t]{2}{*}{ Spring } & Temperature (11) & Nauplii (0.68), total (0.64), \\
\hline & Age-1 alewives (9) & Calanoids $(-0.90)$, diaptomids ( -0.83$)$; cyclopoids C1-C5 (0.90), cyclopoids $(0.79)$ \\
\hline \multirow[t]{7}{*}{$\mathrm{Su}-\mathrm{Au}$} & Su-Au Secchi (12) & Bosmina + Daphnia (-0.80), Daphnia (-0.75), total (-0.60); Bythotrephes (0.72), Epischura C1-C5 (0.61), L. sicilis (0.61) \\
\hline & Su-Au epi Chl (12) & Nauplii $(-0.58)$ \\
\hline & Su-Au meta Chl (11) & Bosmina + Daphnia (0.80), Daphnia (0.75), total (0.72) \\
\hline & Age-1 alewives (10) & Calanoids $(-0.79)$, diaptomids ( -0.66$)$; cyclopoid adults (0.90), cyclopoids $(0.82)$, cyclopoid C1-C5 $(0.75)$ \\
\hline & YAO alewives (11) & Bythotrephes $(-0.62)$ \\
\hline & Limnocalanus adults (12) & Total $(-0.76)$, diaptomids C1-C5 $(-0.73)$, L. ashlandi $(-0.68)$, diaptomids $(-0.60)$ \\
\hline & Bythotrephes (12) & Daphnia $(-0.61)$ \\
\hline \multirow[t]{2}{*}{ Au (predators only) } & Age-0 alewives (10) & Calanoids $(-0.72)$ \\
\hline & Adult alewives (11) & Bythotrephes $(-0.64)$ \\
\hline \multirow[t]{4}{*}{ Annual } & Annual Secchi (11) & Limnocalanus $(0.64)$ \\
\hline & Age-1 alewives (10) & Calanoids $(-0.84)$, diaptomids $(-0.71)$, L. sicilis $(-0.68)$; cyclopoid adults $(0.85)$, cyclopoids $(0.79)$, cyclopoid C1-C5 (0.75) \\
\hline & Limnocalanus (12) & Total $(-0.66)$, nauplii $(-0.62)$, diaptomids C1-C5 $(-0.58)$ \\
\hline & Limnocalanus adults (12) & Total ( -0.65$)$, nauplii $(-0.62)$, L. ashlandi $(-0.59)$, diaptomids C1-C5 $(-0.59)$ \\
\hline
\end{tabular}

zooplankton feeding on zooplankton has been estimated to be about 27\% (Strecker and Arnott, 2008). Thus, the amount of phytoplankton and microzooplankton needed to support a unit of zooplankton biomass during 2007-2008 would be higher than that for the 19942003 time period.

Although zooplankton dynamics ultimately feed back into fish dynamics, we need to consider other food resources and predation as drivers of planktivorous fish abundance. At the same time, macroinvertebrates favored as prey by planktivorous fishes-Diporeia spp. and Mysis-have both decreased with the former species nearly disappearing (Nalepa et al., 2009; Pothoven et al., 2010). Declines in these key macroinvertebrates may ultimately lead to declines in prey fish biomass. For example, declines in Diporeia are associated with the declines in the physiological condition and growth of alewife (Madenjian et al., 2006). Through time, this could result in lower spawning stock biomass and lower fecundity (see Bunnell et al., 2009a) and eventually lead to reduced recruitment for these prey fish species that historically relied upon Diporeia. Whether or not the expansion of quagga mussels in recent years is driving the declines in planktivorous prey fish biomass remains an ongoing debate (see Bunnell et al., 2009b; Nalepa et al., 2009). On the other hand, the decrease in alewife abundance may have been a result of increased predation by Chinook salmon. Predation on alewives by Chinook salmon in Lake Michigan has apparently increased during the 2000 s, and this increased predation was likely responsible for the reduced adult alewife abundance observed during 2007-2008 (Madenjian et al., 2010). A new source of wild Chinook salmon recruitment to Lake Huron, and presumably Lake Michigan as well, was activated sometime during the late 1990s or early 2000 s (Johnson et al., 2010). In addition, the reduction in alewife energy density during the late 1990s was also expected to increase the predation rate on alewives by Chinook salmon in Lake Michigan during the 2000s (Madenjian et al., 2006).

The increase in not only Bythotrephes but also the large calanoids (Limnocalanus, L. sicilis, and Epischura) from pre- to post-expansion periods is consistent with decreased alewife predation since these large zooplankton are the preferred prey of planktivorous fishes, particularly alewives (Davis et al., 2007; Pothoven and Vanderploeg, 2004; Pothoven et al., 2007). Wells (1970) observed that summer abundances of all three large calanoids decreased during the explosion of the alewife population, and these zooplankton species returned to normal, higher levels subsequent of the alewife die off. Our results are even more compelling in that we were able to trace zooplankton populations through all seasons in a continuous time series. It is also possible that the hypolimnetic species benefitted from the decrease in Mysis, a predator of zooplankton (Bowers and
Vanderploeg, 1982), in the latter years of the study (Pothoven et al., 2010). Mysis would likely compete with Limnocalanus for prey since they both prey on zooplankton (Table 1; Bowers and Vanderploeg, 1982) and it is conceivable that Mysis could prey on L. sicilis. Pothoven et al. (2010) hypothesized that the decrease in Mysis was caused by food limitation of the early instars associated with the decimation of the spring diatom bloom.

Interestingly, Barbiero et al. (2009b) observed that August Limnocalanus increased in 2004-2006 relative to abundance in 1984-2003 (with data gaps for 1993-1997 and 2000) and was positively correlated with water clarity $(r=0.66)$ (available for 1998-2006) and negatively correlated with total planktivorous fish abundance over the whole study period. High water clarity was also associated with magnitude of deep Chl layer for which there was a somewhat lower correlation $(r=0.41)$ with Limnocalanus abundance. Barbiero et al. (2009b) reasoned that the deep Chl layer might have been a food source for Limnocalanus. Further, they noted that high abundances of Limnocalanus were associated with years in which water clarity was high and planktivorous fish biomass was low. Although our studies are not strictly comparable either in terms of the years or seasons examined, it is worth noting that the second highest Limnocalanus concentration observed in our study was in 1997, when annual Secchi depth was low $(6.9 \mathrm{~m})$. At this time, age- 0 and age- 1 alewife were low. Thus our results suggest a stronger effect of fish predation than a water clarity-associated increase in the magnitude of the deep Chl layer. We do not have detailed Chl profiles for all years of our study to do a careful analysis of deep Chl layer profiles; however, vertical distribution of Limnocalanus (Vanderploeg, unpublished data) did not show a match with the deep Chl layer, and Limnocalanus feeding and swimming behavior are more adapted to predation on small crustaceans (Table 1 ).

It is likely that these larger calanoids would not be prey of Bythotrephes not only because of their size and fast escape response (Table 1) but also because of the lack of spatial overlap as in the case of L. sicilis and Limnocalanus. Interestingly, L. sicilis was one of the species of zooplankton that increased after Harp Lake was invaded by Bythotrephes (Yan and Pawson, 1997).

Epischura may have actually benefited from expansion of the quagga mussel population because of its ability-unlike other calanoids tested (L. sicilis and Limnocalanus)-to feed efficiently on both trochophore and veliger larvae of dreissenids (Liebig and Vanderploeg, 1995). Dreissena veligers are now abundant during the summer and autumn (Nalepa et al., 2010) in the epi- and metalimnion (Vanderploeg, unpublished data), where they would be subject to predation from Epischura. The mesh size on our net was too coarse to efficiently capture all but the late stages of the larvae because of their small size (Vanderploeg et al., 
1996); therefore we caught very few and did not report their abundance.

The relaxed predation on $L$. sicilis likely mitigated the expected effect of decreased feeding and egg production of $L$. sicilis during the winter-spring transition in the post-expansion period. Bundy et al. (2005) demonstrated that food-phytoplankton and microzooplankton-was limiting to L. sicilis during the 1998 and 1999 winter-spring transition, a time important for egg production. The decrease in nauplii (maxing in spring) during the post-expansion period is consistent with this observation.

A complex combination of resource limitation, predation, and indirect effects of mussels mediated through light likely explains the decrease in Diacyclops, herbivorous cladocerans, and small Leptodiaptomus, L. minutus, and L. ashlandi. Specifically, decreased Chl, direct effects of predation from increased Bythotrephes biomass, and indirect effects of light mediated through increased visual predation by Bythotrephes and increased DVM of prey into less favorable habitats are possible explanations. Increased invertebrate predatory effects were also suggested from the negative correlation seen between Limnocalanus and L. ashlandi and nauplii.

Diacyclops was the only species to display a population crash to nearly zero biomass, and its dynamics were only related to age- 1 alewife (and this was a positive relationship) from a statistical perspective. Wells (1970) also saw this positive relationship during the buildup and die-off of the alewife population. These results are consistent with alewives exhibiting a low preference for small prey (Pothoven and Vanderploeg, 2004; Pothoven et al., 2007) and release from competition with $L$. sicilis, a competitor during the winterspring transition (Table 1). Diacyclops, which could have two to three more generations in summer and autumn after the first generation in April and May (Torke, 1975), could be very responsive to release from competition with its calanoid competitors.

We hypothesize that Diacyclops population crash was related in part to a putative decline in protozoan microzooplankton associated with dreissenid mussels cropping them and their phytoplankton prey in the well-mixed water column during the winter-spring transition (Vanderploeg et al., 2010); this is a case of intraguild predation, with the microzooplankton in the same trophic level as the mussels being preyed upon by the mussels. That is, the protozoans (primarily ciliates), a favored prey of mussels (Lavrentyev et al., 1995), suffered a double blow: direct mortality and reduction of food supply from quagga mussels. Protozoan microzooplankton-primarily ciliateswere identified as a major component of the winter-spring zooplankton community, having a biomass of about the same as the mesozooplankton during $1998-2000$ with L. sicilis obtaining $22-74 \%$ of its ingested $\mathrm{C}$ from the protozoans and the balance from phytoplankton (Bundy et al., 2005; Vanderploeg et al., 2007). As such, they are an important food resource to both diaptomids and Diacyclops. Unlike diaptomids (which have not crashed), which feed on both phytoplankton and microzooplankton, Diacyclops is totally dependent on moving prey (microzooplankton) (Table 1). In terms of impact, the winter-spring transition would be a critical period, when Diacyclops has a major reproductive pulse, and mussel impacts to protozoa would be greatest.

We cannot evaluate the microzooplankton hypothesis because protozoan microzooplankton were not routinely sampled in our long-term program or in any Great Lakes program. This is unfortunate given their important role in controlling phytoplankton and their critical role as food for mesozooplankton (e.g., Bundy et al., 2005; Carrick and Fahnenstiel, 1990; Carrick et al., 1991; Weisse, 2006). Circumstantial evidence for the sensitivity of microzooplankton to mussel feeding comes from winter-spring observations of Vanderploeg et al. (2007) which demonstrated that microzooplankton abundance decreased to a greater degree than phytoplankton at inshore stations, where dreissenid mussels were expected to be abundant on the rocky substrate, relative to offshore stations near Chicago.
In addition to the probable detriment to Diacyclops by loss of microzooplankton during the winter-spring transition, it is possible that predation on its early life stages by Bythotrephes is another factor. There is spatial overlap of copepodite (and naupliar) stages of Diacyclops with Bythotrephes during summer and autumn, when these stages are most abundant (Table 1). Bythotrephes has the following order of prey preference: cladocerans $>$ nauplii $>$ copepodites and adult copepods (Schulz and Yurista, 1998; Vanderploeg et al., 1993). Capture probability is strongly affected by escape speeds of the prey (Pichlová-Ptáčníková and Vanderploeg, 2011). It is likely the nauplii and copepodite stages of Diacyclops, a small species relative to most calanoids, would be vulnerable to predation since escape speeds are a function of prey size (Link, 1996) within copepods. The same spatial overlap and predation vulnerability may also apply to nauplii and copepodite stages of L. minutus and L. ashlandi, which also have a second generation during summer (Torke, 1975).

Overall, the impact of all forces has been greatest on epilimnetic and metalimnetic species (Diacyclops, L. minutus, L. ashlandi, Bosmina, Daphnia, and copepod nauplii). Similar patterns appeared somewhat earlier in Lake Huron, so it is likely that many of the same forces are playing out in both systems (Barbiero et al., 2009a; Riley et al., 2008).

In Lake Michigan, the recent increase in Bythotrephes and its high consumption rate $(\sim 100 \%$ of its body weight per day; Yurista et al., 2010) would be expected to have an important impact, especially considering its high biomass relative to potential favored epilimnetic prey like Daphnia, Bosmina, copepod nauplii, and Diacyclops copepodites and adults that occur in summer. Note that average annual abundance of Bythotrephes relative to these prey was only 0.03 during the pre-expansion period but climbed to 0.46 during the postexpansion period. It therefore seems likely that Bythotrephes were having a strong direct effect on these overlapping epilimnetic-metalimnetic prey, as well as contributing indirectly to energetic costs to species like $D$. mendotae that vertically migrate into cool, suboptimal feeding habitats to avoid high concentrations of Bythotrephes (Pangle and Peacor, 2006).

This study and the study of Makarewicz et al. (1995), which examined August data from U.S. EPA summer cruises during 1983-1992, a period of highly variable abundance of forage fish and the initial invasion of Bythotrephes, both point to the potential importance of fishes and Bythotrephes as important controllers of zooplankton in Lake Michigan. In fact, Bythotrephes can be even more important controllers of zooplankton than fish because of Bythotrephes' high abundance and high weight-specific feeding rate relative to fish, as evidenced by a 2007 study in Lake Huron in 2007 (Bunnell et al., 2011). Clearly, as planktivorous alewives have decreased in abundance, there has been a shift from vertebrate (alewife) to invertebrate (Bythotrephes) impacts.

The large immediate changes in zooplankton community structure seen in Lake Michigan and other lakes following the Bythotrephes invasion (e.g., Lehman, 1987, 1991; Yan and Pawson, 1997) may be related to escape abilities of prey (Pichlová-Ptáčníková and Vanderploeg, 2011). In Lake Michigan, Daphnia pulicaria and D. retrocurva, which had slow escape speeds relative to $D$. mendotae and calanoid copepods, disappeared immediately after the Bythotrephes invasion. Note this immediate change was not presaged by any warning signals of a tipping point (e.g., Scheffer, 2010) other than the appearance of the invader itself.

Now we have moved into a phase where decreased TP concentration, decreased forage fishes, and increased mussel abundance have led to cascading synergistic interactions between mussels and Bythotrephes. The increased pressure from these synergistic interactions is putting further pressure on the plankton community that survived the initial Bythotrephes invasion. We do know that mussel populations have continued to expand, at least until 2010; therefore, these interactions would be expected to put further stress on the 
zooplankton community and the fish it supports. Particularly vulnerable would be the age- 0 fishes and the "obligate" planktivores such as alewives.

Although we saw a positive correlation of total spring zooplankton and nauplii with spring water temperature, a result consistent with temperature-driven effects on phenology, we did not observe a correlation of annual zooplankton biomass with annual average surface temperature. Early development of Daphnia populations and the clear water phase typically associated with Daphnia occurred earlier in European lakes during warm springs associated with the North Atlantic Oscillation (Gerten and Adrian, 2000; Straile and Adrian, 2000). Translating changes in weather or climate to an impact on zooplankton in Lake Michigan will be extremely difficult given the disrupted nature of its food web. For Lake Michigan, the most striking effect of weather likely occurred through its impact on the strength of the alewife year class in 1998. It certainly is possible that the fast development of the zooplankton population that year provided a useful match in food availability (Durant et al., 2007) for the larval alewife that year.

\section{Implications and future research}

It is of great management importance to foresee tipping points, and this is an emerging science (Scheffer, 2010). There is no substitute for comprehensive long-term data to reveal the dynamics of complex ecosystems, provide perspective on the current state of the system (Magnuson, 1990), and offer clues regarding pending regime shifts (Carpenter et al., 2011; Scheffer, 2010). Whether changes occur as sudden shifts or as gradual trends, it is necessary to have sufficient data for these patterns to be discernable (Reckhow and Stow, 1990).

The question might be asked as to whether the Lake Michigan data set offered any clues as to a possible tipping point or regime shift and when this occurred. We were very familiar with the impacts of dreissenids and other invaders in shallow areas of the Great Lakes and had predicted that if dreissenids were to move into deep water they would have their greatest impact during winter and spring (Vanderploeg et al., 2002). In autumn of 2003, we had become aware of the incipient replacement of zebra mussels by quagga mussels in shallow waters and their movement into deep water on soft substrates previously not colonized by zebra mussels (e.g., Nalepa et al., 2010). This and a low Chl concentration seen in Lake Michigan that year alerted us to an incipient regime shift. Of course, there could be annual variability in Chl from different sources such as variations in P loading (e.g., Mida et al., 2010), but the incipient expansion was in our minds a clear signal. In particular, we note that the low Chl in 2003 was consistent with low TP loading that year (Mida et al., 2010). Ironically, funding priorities shifted and the program was dropped for 3 years until it was resumed in 2007.

We have clearly demonstrated the value of long-term seasonal studies of zooplankton for describing status of the plankton community and potential driving variables in a Great Lake. Data gaps compromised the time series, particularly during the 2004-2006, when the system was in a transition. Nevertheless, valuable insights were obtained. The importance of seasonal sampling every year is made clear by the connectedness of results from one year to another, as is obvious from the profound change from 1998 to 1999 which was related to development of the strong alewife year-class of 1998 .

These insights would have been more difficult to obtain from only spring and summer surveys conducted every year on the Great Lakes because the dynamics in the system cannot be captured in twice a year sampling. Implicit in this approach has been the assumption that summer surveys capture a summer steady state condition (Barbiero et al., 2001). This is clearly not the case, and different species can have very different times of maximum abundance that do not necessarily coincide with the August sampling. In particular, we saw that Bythotrephes, arguably one of the most important drivers of change, has its maximum abundance in November.

Future work should focus on continuing the methodical collection time series of data including protozoan microzooplankton, as they are consumers of phytoplankton and major food for mesozooplankton. There is not a good foundation of empirical observations to predict effects of reoligotrophication on food webs of large lakes (Jeppesen et al., 2005) and certainly not for Lake Michigan, which has been so profoundly affected by non-indigenous species.

For Lake Michigan, the seasonal time series themselves were useful to pointing out potential interactions as well as defining an average annual biomass. Evolving quantitative approaches such as structural equation modeling (Shipley, 2000) have the potential to provide powerful tools for explaining the causes of change in complex dynamical systems when supported with adequate, comprehensive, long-term data. Considering the spatial complexity of Lake Michigan, spatial coupling of mussels, nutrients, plankton, and fishes, as well as the processes connecting them, requires further study. In particular, it is obvious that average Chl concentration is not necessarily a useful metric for food abundance. Zooplankton may exploit areas of high concentration such as metalimnetic maxima or other maxima such as deep Chl layers and the microzooplankton found in them. In addition, quality of the food (phytoplankton and microzooplankton) is important nutritionally as well as size and morphology and other features that affect the capture, ingestion, and subsequent utilization of the prey (e.g., Vanderploeg, 1994).

\section{Acknowledgments}

We thank R. Pichlová-Ptáčníková and the captains and crews of the R/V Shenehon and R/V Laurentian, namely D. Donahue, J. Workman, and A. Yagiella, for help in field collections. H. Carrick made helpful comments on an early version of this manuscript. Partial support for funding came from NOAA Coastal Ocean Program and the Great Lakes Fishery Commission. This is GLERL Contribution No. 1620 and U.S. Geological Survey Great Lakes Science Center Contribution No. 1684

\section{References}

Balcer, M.D., Korda, N.L., Dodson, S.I., 1984. Zooplankton of the Great Lakes-A Guide to the Identification and Ecology of Common Crustacean Species. University of Wisconsin Press, Madison.

Barbiero, R.P. Little, R.E. Tuchman, M.L, 2001. Results from the U.S. EPA's Biological Open Water Surveillance Program of the Laurentian Great Lakes III: crustacean zooplankton. J. Great Lakes Res. 27, 167-184.

Barbiero, R.P. Schacht, L.L, Little, R.E. Tuchman, M.L, 2005. Crustacean zooplankton communities in Lake Michigan. In: Edsall, T., Munawar, M. (Eds.), State of Lake Michigan: Ecology, Health, and Management. Aquatic Ecosystems Health and Management Society, New Delhi, pp. 237-267.

Barbiero, R.P. Balcer, M., Rockwell, D.C., Tuchman, M.L, 2009a. Recent shifts in the crustacean zooplankton community of Lake Huron. Can. J. Fish. Aquat. Sci. 66, 816-828.

Barbiero, R.P., Bunnell, D.B., Rockwell, D.C., Tuchman, M.L., 2009b. Recent increases in the large glacial-relict calanoid Limnocalanus macrurus in Lake Michigan. J. Great Lakes Res. 35, 285-292.

Bowers, J.A., Vanderploeg, H.A., 1982. In situ predatory behavior of Mysis relicta in Lake Michigan. Hydrobiologia 93, 121-131.

Brandt, S.B., Magnuson, J.J., Crowder, L.B., 1980. Thermal habitat partitioning by fishes in Lake Michigan. Can. J. Fish. Aquat. Sci. 37, 1557-1564.

Branstrator, D.K., Lehman, J.T., 1996. Evidence for predation by young-of-the-year alewife and bloater chub on Bythotrephes cederstroemi in Lake Michigan. J. Great Lakes Res. 22, 917-924.

Brooks, J.L., 1959. Cladocera. In: Edmondson, W.T. (Ed.), Freshwater Biology. John Wiley and Sons, New York, pp. 587-656.

Brooks, A.S., Torke, B.G., 1977. Vertical and seasonal distribution of chlorophyll a in Lake Michigan. J. Fish. Res. Board Can. 34, 2280-2287.

Bundy, M.H., Gross, T.F., Vanderploeg, H.A., Strickler, J.R., 1998. Perception of inert particles by calanoid copepods: behavioral observations and a numerical model. J. Plankton Res. 20, 2129-2152.

Bundy, M.H., Vanderploeg, H.A., Lavrentyev, P.J., Kovalcik, P.A., 2005. The importance of microzooplankton versus phytoplankton to copepod populations during late winter and early spring in Lake Michigan. Can. J. Fish. Aquat. Sci. 62, 2371-2385. 
Bunnell, D.B., Madenjian, C.P., Claramont, R.M., 2006. Long-term changes of the Lake Michigan fish community following the reduction of exotic alewife (Alosa pseudoharengus). Can. J. Fish. Aquat. Sci. 63, 2434-2446.

Bunnell, D.B., David, S.R., Madenjian, C.P., 2009a. Decline in bloater fecundity in southern Lake Michigan: effect of Diporeia decline? J. Great Lakes Res. 35, 45-49.

Bunnell, D.B., Madenjian, C.P., Holuszko, J.D., Adams, J.V., French, J.R.P., 2009b. Expansion of Dreissena into offshore waters of Lake Michigan and potential impacts on fish populations. J. Great Lakes Res. 35, 74-80.

Bunnell, D.B., Davis, B.M., Warner, D.M., Chriscinske, M.A., Roseman, E.F., 2011. Planktivory in the changing Lake Huron zooplankton community: Bythotrephes consumption exceeds that of Mysis and fish. Freshwater Biol. 56, 1281-1296.

Burns, C.W., Gilbert, J.J., 1993. Predation on ciliates by freshwater calanoid copepods-rates of predation and relative vulnerabilities of prey. Freshwater Biol. 30, 377-393.

Carpenter, S.R., Cole, J.J., Pace, M.L., Batt, R., Brock, W.A., Cline, T., Coloso, J., Hodgson, J.R., Kitchell, J.F., Seekell, D.A., Smith, L., Weidel, B., 2011. Early warnings of regime shifts: a whole-ecosystem experiment. Science 332, 1079-1082.

Carrick, H.J., Fahnenstiel, G.L., 1990. Planktonic protozoa in Lakes Huron and Michigan: seasonal abundance and composition of ciliates and dinoflagellates. J. Great Lakes Res. 16, 319-329.

Carrick, H.J., Fahnenstiel, G.L., Stoermer, E.F., Wetzel, R.G., 1991. The importance of zooplankton protozoan trophic couplings in Lake Michigan. Limnol. Oceanogr. 36, 1335-1345.

Culver, D.A., Boucerle, M.M., Bean, D.J., Fletcher, J.W., 1985. Biomass of freshwater crustacean zooplankton from length weight regressions. Can. J. Fish. Aquat. Sci. 42, 1380-1390.

Davis, B.M., Savino, J.F., Ogilvie, L.M., 2007. Diet niches of major forage fish in Lake Michigan. Adv. Limnol. 60, 261-275.

Doubek, J.P., Lehman, J.T., 2011. Historical biomass of Limnocalanus in Lake Michigan. J. Great Lakes Res. 37, 159-164.

Drenner, R.W., McComas, S.R., 1980. The role of zooplankter escape ability in the selective feeding and impact of planktivorous fish. In: Kerfoot, W.C. (Ed.), Evolution and Ecology of Zooplankton Communities. The University Press of New England, Hannover, New Hampshire, pp. 587-593.

Durant, J.M., Hjermann, D.O., Ottersen, G., Stenseth, N.C., 2007. Climate and the match or mismatch between predator requirements and resource availability. Clim. Res. 33, 271-283.

Evans, M.S., 1990. Large-lake responses to declines in the abundance of a major fish planktivore: the Lake Michigan example. Can. J. Fish. Aquat. Sci. 47, 1738-1754.

Fahnenstiel, G.L., Pothoven, S.A., Nalepa, T.F., Vanderploeg, H.A., Klarer, D., Scavia, D., 2010. Recent changes in primary production and phytoplankton in the offshore region of southeastern Lake Michigan. J. Great Lakes Res. 36 (Suppl. 3), 30-41.

Gerten, D., Adrian, R., 2000. Climate-driven changes in spring plankton dynamics and the sensitivity of shallow polymictic lakes to the North Atlantic Oscillation. Limnol. Oceanogr. 45, 1058-1066.

Haney, J.F., Hall, D.J., 1973. Sugar coated Daphnia: a preservation technique for Cladocera. Limnol. Oceanogr. 18, 331-332.

Hatch, R.W., Haack, P.M., Brown, E.H., 1981. Estimation of alewife biomass in Lake Michigan, 1967-1978. Trans. Am. Fish. Soc. 110, 575-584.

Hawkins, B.E., Evans, M.S., 1979. Seasonal cycles of zooplankton biomass in southeastern Lake Michigan. Int. Assoc. Great Lakes Res. 5, 256-263.

Hecky, R.E., Smith, R.E.H., Barton, D.R., Gulidford, S.J., Taylor, W.D., Charlton, M.N., Howell, T., 2004. The nearshore phosphorus shunt: a consequence of ecosystem engineering by dreissenids in the Laurentian Great Lakes. Can. J. Fish. Aquat. Sci. $61,1284-1293$.

Jeppesen, E., Sondergaard, M., Jensen, J.P., Havens, K.E., Anneville, O., Carvalho, L., Coveney, M.F., et al., 2005. Lake responses to reduced nutrient loading - an analysis of contemporary long-term data from 35 case studies. Freshwater Biol. 50, 1747-1771.

Johnson, J.E., DeWitt, S.P., Gonder, D.J.A., 2010. Mass-marking reveals emerging self regulation of the Chinook salmon population in Lake Huron. North Am. J. Fish. Manag. 30, 518-529.

Kerfoot, W.C., Foad, Y., Green, S.A., Budd, J.W., Schwab, D.J., Vanderploeg, H.A., 2010. Approaching storm: disappearing winter bloom in Lake Michigan. J. Great Lakes Res. 36 (Suppl. 3), 30-41.

Lavrentyev, P.J., Gardner, W.S., Cavaletto, J.F., Beaver, J.R., 1995. Effects of the zebra mussel (Dreissena polymorpha Pallas) on protozoa and phytoplankton from Saginaw Bay, Lake Huron. J. Great Lakes Res. 21, 545-557.

LeBlanc, J.S., Taylor, W.D., Johannsson, O.E., 1997. The feeding ecology of the cyclopoid copepod Diacyclops thomasi in Lake Ontario. J. Great Lakes Res. 23, 369-381.

Lehman, J.T., 1987. Palearctic predator invades North American Great Lakes. Oecologia $74,478-480$

Lehman, J.T., 1991. Causes and consequences of cladoceran dynamics in Lake Michigan: implications of species invasion by Bythotrephes. J. Great Lakes Res. 17, 437-445.

Liebig, J.R., Vanderploeg, H.A., 1995. Vulnerability of Dreissena polymorpha larvae to predation by Great Lakes calanoid copepods: the importance of the bivalve shell. J. Great Lakes Res. 21, 353-358.

Liebig, J.R., Vanderploeg, H.A., 2008. Selecting optical plankton counter size bins to optimize zooplankton information in Great Lakes studies. NOAA Technical Memorandum GLERL-143. ftp://ftp.glerl.noaa.gov/publications/tech_reports/glerl-143/tm143.pdf.

Link, J., 1996. Capture probabilities of Lake Superior zooplankton by an obligate planktivorous fish - the lake herring. Trans. Am. Fish. Soc. 125, 139-142.

Madenjian, C.P., Fahnenstiel, G.L., Johengen, T.H., Nalepa, T.F., Vanderploeg, H.A. Fleischer, G.W., Schneeberger, P.J., Benjamin, D.M., Smith, E.B. Bence, J.R. Rutherford, E.S., Lavis, D.S., Robertson, D.M., Jude, D.J., Ebener, M.P., 2002. Dynamics of the Lake Michigan food web, 1970-2000. Can. J. Fish. Aquat. Sci. 59, 736-753.

Madenjian, C.P., Hook, T.O., Rutherford, E.S., Mason, D.M., Croley, T.E., Szalai, E.B., Bence J.R., 2005. Recruitment variability of alewives in Lake Michigan. Trans. Am. Fish. Soc. $134,218-230$.
Madenjian, C.P., Pothoven, S.A., Dettmers, J.M., Holuszko, J.D., 2006. Changes in seasonal energy dynamics of alewife (Alosa pseudoharengus) in Lake Michigan after invasion of dreissenid mussels. Can. J. Fish. Aquat. Sci. 63, 891-902.

Madenjian, C.P., Bunnell, D.B., Holuszko, J.D., Desorcie, T.J., Adams, J.V., 2010. Status and Trends of Prey Fish Populations in Lake Michigan, 2009. U. S. Geological Survey, Great Lakes Science Center, Ann Arbor, Michigan. (Available from:) http://www glsc.usgs.gov/_files/reports2009LakeMichiganPreyfish.pdf. (May 2011).

Magnuson, JJ 1990. Long-term ecological research and the invisible present - uncovering the processes hidden because they occur slowly or because effects lag years behind causes. Bioscience 40, 495-501.

Makarewicz, J.C., Jones, H.D., 1990. Occurrence of Bythotrephes cederstroemi in Lake Ontario offshore waters. J. Great Lakes Res. 16, 143-147.

Makarewicz, J.C., Bertram, P., Lewis, T., Brown, E.H., 1995. A decade of predatory contro of zooplankton species composition of Lake Michigan. J. Great Lakes Res. 21, 620-640

Malley, D.F., Lawrence, S.G., MacIver, M.A., Findlay, W.J., 1989. Range of variation in es timates of dry weight for planktonic Crustacea and Rotifera from temperate North American lakes. Can. Tech. Rep. Fish. Aquat. Sci., No. 1666. Dept. of Fisheries and Oceans, Winnipeg, Manitoba.

Mida, J.L., Scavia, D., Fahnenstiel, G.L., Pothoven, S.A., Vanderploeg, H.A., Dolan, D.M., 2010. Long-term and recent changes in southern Lake Michigan water quality with implications for present trophic status. J. Great Lakes Res. 36, 42-49.

Muirhead, J., Sprules, W.G., 2003. Reaction distance of Bythotrephes longimanus, encounter rate and index of prey risk for Harp Lake, Ontario. Freshwater Biol. 48 135-146.

Nalepa, T.F., Fanslow, D.L., Lang, G.A., 2009. Transformation of the offshore benthic community in Lake Michigan: recent shift from the native amphipod Diporeia spp. to the invasive mussel Dreissena rostriformis bugensis. Freshwater Biol. 54 466-479.

Nalepa, T.F., Fanslow, D.L., Pothoven, S.A., 2010. Recent changes in density, biomass, recruitment, size structure, and nutritional state of Dreissena populations in southern Lake Michigan. J. Great Lakes Res. 36, 5-19.

Pangle, K.L., Peacor, S.D., 2006. Non-lethal effect of the invasive predator Bythotrephes longimanus on Daphnia mendotae. Freshwater Biol. 51, 1070-1078.

Pangle, K.L., Peacor, S.D., 2009. Light-dependent predation by the invertebrate planktivore Bythotrephes longimanus. Can. J. Fish. Aquat. Sci. 66, 1748-1757.

Pichlová-Ptáčníková, R., Vanderploeg, H.A., 2011. The quick and the dead: might differences in escape rates explain the changes in zooplankton community composition of Lake Michigan after invasion by Bythotrephes? Biol. Invasions 13, 2595-2604.

Pothoven, S.A., Vanderploeg, H.A., 2004. Diet and prey selection of alewives in Lake Michigan: seasonal, depth, and interannual patterns. Trans. Am. Fish. Soc. 133, 1068-1077.

Pothoven, S.A., Vanderploeg, H.A., Cavaletto, J.F., Krueger, D.M., Mason, D.M., Brandt S.B., 2007. Alewife planktivory controls the abundance of two invasive predatory cladocerans in Lake Michigan. Freshwater Biol. 52, 561-573.

Pothoven, S.A., Fahnenstiel, G.L., Vanderploeg, H.A., 2010. Temporal trends in Mysis relicta abundance, production, and life history characteristics in southeastern Lake Michigan. J. Great Lakes Res. 36 (Suppl. 3), 60-64.

Reckhow, K.H., Stow, C.A., 1990. Monitoring design and data analysis for trend detection. Lake Reservoir Manage. 6, 49-60.

Riley, S.C., Roseman, E.F., Nichols, S.J., O'Brien, T.P., Kiley, C.S., Schaeffer, J.S., 2008. Deepwater demersal fish community collapse in Lake Huron. Trans. Am. Fish. Soc. 137, 1879-1890.

Satterthwaite, F.W., 1946. An approximate distribution of estimates of variance components. Biometrics Bull. 2, 110-114.

Scavia, D., Fahnenstiel, G.L., Evans, M.S., Jude, D.J. Lehman, JT, 1986. Influence of salmonine predation and weather on long-term water quality trends in Lake Michigan. Can. J. Fish. Aquat. Sci. 43, 435-443.

Scheffer, M., 2010. Foreseeing tipping points. Nature 467, 411.

Schulz, K.L., Yurista, P.M. 1998. Implications of an invertebrate predator's (Bythotrephes cederstroemi) atypical effects on a pelagic zooplankton community. Hydrobiologia 380, 179-193.

Shipley, B., 2000. Cause and Correlation in Biology. Cambridge University Press.

Straile, D., Adrian, R., 2000. The North Atlantic Oscillation and plankton dynamics in two European lakes - two variations on a general theme. Glob. Chang. Biol. 6, 663-670.

Strecker, A.L., Arnott, S.E., 2008. Invasive predator, Bythotrephes, has varied effects on ecosystem function in freshwater lakes. Ecosystems 11, 490-503.

Torke, B., 1975. The population dynamics and life histories of crustacean zooplankton at a deep-water station. Ph.D. Thesis, The University of Wisconsin-Madison, 91 pp.

Vanderploeg, $\mathrm{H}$, 1994. Zooplankton particle selection and feeding mechanisms. In: Wotton, R.S. (Ed.), The Biology of Particles in Aquatic Systems. Lewis Publishers, Ann Arbor, pp. 205-234

Vanderploeg, H.A., Paffenhöfer, G.-A., Liebig, J.R., 1988. Diaptomus vs. net phytoplankton: effects of algal size and morphology on selectivity of behaviorally flexible, omnivorous copepod. Bull. Mar. Sci. 43, 377-394

Vanderploeg, H.A., Gardner, W.S., Parrish, C.C., Liebig, J.R., Cavaletto, J.F., 1992. Lipids and life-cycle strategy of a hypolimnetic copepod in Lake Michigan. Limnol. Oceanogr. 37, 413-424.

Vanderploeg, H.A., Liebig, J.R., Omair, M., 1993. Bythotrephes predation on Great Lakes zooplankton measured by an in situ method: implications for zooplankton community structure. Arch. Hydrobiol. 127, 1-8.

Vanderploeg, H.A., Liebig, J.R., Gluck, A.A., 1996. Evaluation of different phytoplankton for supporting development of zebra mussel larvae (Dreissena polymorpha) the importance of size and polyunsaturated fatty acid content. J. Great Lakes Res. $22,36-45$. 
Vanderploeg, H.A., Cavaletto, J.F., Liebig, J.R., Gardner, W.S., 1998. Limnocalanus macrurus (Copepoda: Calanoida) retains a marine arctic lipid and life cycle strategy in Lake Michigan. J. Plankton Res. 20 (8), 1581-1597.

Vanderploeg, H.A., Nalepa, T.F., Jude, D.J., Mills, E.L., Holeck, K.T., Liebig, J.R., Grigorovich, I.A Ojaveer, H., 2002. Dispersal and emerging ecological impacts of Ponto-Caspian species in the Laurentian Great Lakes. Can. J. Fish. Aquat. Sci. 59, 1209-1228.

Vanderploeg, H.A., Johengen, T.H., Lavrentyev, P.J., Chen, C., Lang, G.A., Agy, M.A. Bundy, M.H., Cavaletto, J.F., Eadie, B.J., Liebig, J.R., Miller, G.S., Ruberg, S.A. McCormick, M.J., 2007. Anatomy of the recurrent coastal sediment plume in Lake Michigan and its impacts on light climate, nutrients, and plankton. J. Geophys. Res. Oceans 112, C03S90. doi:10.1029/2004JC002379.

Vanderploeg, H.A., Ludsin, S.A., Cavaletto, J.F., Hook, T.O., Pothoven, S.A., Brandt, S.B., Liebig J.R., Lang, G.A., 2009. Hypoxic zones as habitat for zooplankton in Lake Erie: refuges from predation or exclusion zones? J. Exp. Mar. Biol. Ecol. 381, S108-S120.

Vanderploeg, H.A., Liebig, J.R., Nalepa, T.F., Fahnenstiel, G.L., Pothoven, S.A., 2010. Dreis sena and the disappearance of the spring phytoplankton bloom in Lake Michigan. J. Great Lakes Res. 36 (Suppl. 3), 50-59.

Wang, J., Bai, X., Leshkevich, G., Colton, M., Clites, A., Lofgren, B., 2010. Severe ice cover on Great Lakes during winter 2008-2009. Eos Trans. Am. Geophys. Union 91, 41-42.

Warner, D.M., Claramunt, R.M., Houszko, J.D., Desorcie, T., 2009. Status of Prey Fishes and Pelagic Macroinvertebrates in Lake Michigan, 2008. U.S. Geological Survey Great Lakes Science Center, Ann Arbor, Michigan. (Available from:) http://www. glsc.usgs.gov/_files/reports/2008LakeMichiganAcoustic.pdf.
Warren, G.J., 1985. Predaceous feeding habits of Limnocalanus macrurus. J. Plankton Res. 7, 537-552.

Weisse, T., 2006. Freshwater ciliates as ecophysiological model organisms - lessons from Daphnia, major achievements, and future perspectives. Arch. Hydrobiol. 167, 371-402.

Wells, L., 1968. Seasonal depth distribution of fish in southeastern Lake Michigan. Fish. Bull. 67, 1-15.

Wells, L., 1970. Effects of alewife predation on zooplankton populations in Lake Michigan. Limnol. Oceanogr. 15, 556-565.

Wilson, M.S., Yeatman, H.C., 1959. Free-living Copepoda. In: Edmondson, W.T. (Ed.), Freshwater Biology. John Wiley and Sons, New York, pp. 735-861.

Wong, C.K., 1981. Predatory feeding behavior of Epischura lacustris (Copepoda, Calanoida) and prey defence. Can. J. Fish. Aquat. Sci. 38, 275-279.

Wright, D., O'Brien, W.J., Vinyard, G.L., 1980. Adaptive value of vertical migration: a simulation model argument for the predation hypothesis. In: Kerfoot, W.C. (Ed.), Evolution and Ecology of Zooplankton Communities. University Press of New England, Hanover, New Hampshire, pp. 138-157.

Yan, N.D., Pawson, T.W., 1997. Changes in the crustacean zooplankton community of Harp Lake, Canada, following invasion by Bythotrephes cederstroemi. Freshwater Biol. 37, 409-425.

Yurista, P.M., Vanderploeg, H.A., Liebig, J.R., Cavaletto, J.F., 2010. Lake Michigan Bythotrephes prey consumption estimates for 1994-2003 using a temperature and size corrected bioenergetic model. J. Great Lakes Res. 36 (Suppl. 3), 74-82. 